Article

\title{
The Antifungal Action Mode of $N$-Phenacyldibromobenzimidazoles
}

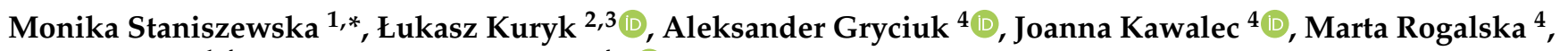 \\ Joanna Baran ${ }^{1,4}$ and Anna Kowalkowska $4, *$ (D) \\ 1 Centre for Advanced Materials and Technologies CEZAMAT, Warsaw University of Technology, Poleczki 19, \\ 02-822 Warsaw, Poland; jbaran@ch.pw.edu.pl \\ 2 Department of Virology, National Institute of Public Health-National Institute of Hygiene, Chocimska 24, \\ 00-791 Warsaw, Poland; lkuryk@pzh.gov.pl \\ 3 Clinical Science, Targovax Oy, Lars Sonckin Kaari 14, Espoo Stella Luna Business Park, 02600 Espoo, Finland \\ 4 Faculty of Chemistry, Warsaw University of Technology, Noakowskiego St 3, 00-664 Warsaw, Poland; \\ alek.gryciuk@gmail.com (A.G.); joanna.kawalec.stud@pw.edu.pl (J.K.); martarogalska98@gazeta.pl (M.R.) \\ * Correspondence: monika.staniszewska@pw.edu.pl (M.S.); anna.kowalkowska@pw.edu.pl (A.K.)
}

check for updates

Citation: Staniszewska, M.; Kuryk, Ł.; Gryciuk, A.; Kawalec, J.; Rogalska, M.; Baran, J.; Kowalkowska, A. The Antifungal Action Mode of $N$-Phenacyldibromobenzimidazoles. Molecules 2021, 26, 5463. https:// doi.org/10.3390/molecules26185463

Academic Editor: Sławomir Milewski

Received: 1 August 2021

Accepted: 2 September 2021

Published: 8 September 2021

Publisher's Note: MDPI stays neutral with regard to jurisdictional claims in published maps and institutional affiliations.

Copyright: (c) 2021 by the authors. Licensee MDPI, Basel, Switzerland. This article is an open access article distributed under the terms and conditions of the Creative Commons Attribution (CC BY) license (https:// creativecommons.org/licenses/by/ $4.0 /)$.

\begin{abstract}
Our study aimed to characterise the action mode of $N$-phenacyldibromobenzimidazoles against $C$. albicans and C. neoformans. Firstly, we selected the non-cytotoxic most active benzimidazoles based on the structure-activity relationships showing that the group of 5,6-dibromobenzimidazole derivatives are less active against $C$. albicans vs. 4,6-dibromobenzimidazole analogues (5e-f and $5 \mathbf{h}$ ). The substitution of chlorine atoms to the benzene ring of the $N$-phenacyl substituent extended the anti-C. albicans action (5e with $2,4-\mathrm{Cl}_{2}$ or $5 \mathbf{f}$ with $3,4-\mathrm{Cl}_{2}$ ). The excellent results for $\mathrm{N}$-phenacyldibromobenzimidazole $\mathbf{5 h}$ against the $\mathrm{C}$. albicans reference and clinical isolate showed $\mathrm{IC}_{50}=8 \mu \mathrm{g} / \mathrm{mL}$ and $\% \mathrm{I}=100 \pm 3$, respectively. Compound $5 \mathrm{~h}$ was fungicidal against the $C$. neoformans isolate. Compound $5 \mathrm{~h}$ at $160-4 \mu \mathrm{g} / \mathrm{mL}$ caused irreversible damage of the fungal cell membrane and accidental cell death (ACD). We reported on chitinolytic activity of $\mathbf{5 h}$, in accordance with the patterns observed for the following substrates: 4-nitrophenyl- $N$-acetyl- $\beta$-D-glucosaminide and 4-nitrophenyl- $\beta$-D- $N, N^{\prime}, N^{\prime \prime}$-triacetylchitothiose. Derivative $5 \mathbf{h}$ at $16 \mu \mathrm{g} / \mathrm{mL}$ : (1) it affected cell wall by inducing $\beta$-D-glucanase, (2) it caused morphological distortions and (3) osmotic instability in the C. albicans biofilm-treated. Compound $5 \mathrm{~h}$ exerted Candida-dependent inhibition of virulence factors.
\end{abstract}

Keywords: N-phenacyldibromobenzimidazoles; Candida spp.; Cryptococcus neoformans; action mode

\section{Introduction}

Studies conducted during the past two decades have documented changes in the causative agents of nosocomial blood stream infections, and emphasized an increase of very critical fungal infections, particularly due to Candida spp. and Cryptococcus spp. [1] The emergence of antifungal resistance required more concern to find out effective antimycotics with novel modes of action. Thus, introduction of $N$-phenacyldibromobenzimidazoles as another antimycotics destroying the fungal cell wall and membrane may be a milestone in the development of antifungal therapies. Moreover, treatment with anti-filamentation compound benefits the host by modulating immune responses [1]. An inhibition of morphological switch may provide an alternative approach to finding compounds with a potential to control the Candida albicans infections [2]. Morphogenesis is critical for biofilm formation, thus compounds able to inhibit sessile growth are needed [3].

Azoles are easy-to-use scaffolds in antifungal drug discovery [4]. Moreover, azoles are often functionalized with phenacyl group as a result of $N$-alkylation to gain excellent antifungal activity. There are known as biologically active $N$-phenacyl imidazoles [5-10], benzimidazoles [11-14], triazoles $[5,7,15]$ or pyrazoles $[16,17]$. $N$-phenacyl azoles are often used as substrates for further synthesis of antifungal active agents [7,9-11,13-15,18-20]. 
In this study, we focused on dibromobenzimidazole synthesis due to promising antifungal activity rarely undertaken by scientists in worldwide studies on drug discovery, probably due to tedious synthesis [21-24].

We evaluated the toxicity of various $N$-phenacyldibromobenzimidazoles towards a mammalian cell line as well as the fungistatic and fungicidal effect against the $C$. albicans and Cryptococcus neoformans reference and clinical isolates resistant to azoles and echinocandins. The experiments with $\mathrm{N}$-phenacyldibromobenzimidazoles have been encouraging in the current study because of the following action modes need to be assessed: 1 . Phosphatidylserine externalization affecting subsequently the chitin content; 2. Cell wall stress induced by $N$-phenacyldibromobenzimidazoles resulted in the decreased/ increased ROS; 3. Lysosomotropic $N$-phenacyldibromobenzimidazoles exerted direct membrane lyses and caused osmotic pressure; 4 . The concept regarding extensity of accidental cell death (ACD) under $N$-phenacyldibromobenzimidazoles. Since the primary targets of commercially available antimycotics are $\beta-1.3$-glucan and ergosterol, respectively, we underwent study if any compensatory mechanism in the cell wall and membrane occurs after the $\mathrm{N}$-phenacyldibromobenzimidazole treatment. In our study, morphological changes enabled $\mathrm{N}$-phenacyldibromobenzimidazoles gaining access to intracellular targets by facilitating membrane transience.

\section{Results}

\subsection{Synthesis of N-Phenacyldibromobenzimidazoles}

As it is shown in Table 1 and Scheme 1, compounds $\mathbf{4 - 5}$ were synthesized by $\mathrm{N}$-alkylation of 5,6-dibromobenzimidazole 1 or 4,6-dibromobenzimidazole 2 with phenacyl chlorides or bromides 3 in the presence of $\mathrm{K}_{2} \mathrm{CO}_{3}$ in $\mathrm{MeCN}$. The time of the reactions as well as the yields depended on the structure of the phenacyl derivative 3 used. In the case of unsubstituted phenacyl bromide $\mathbf{3 a}$ and monofunctionalized derivatives $\mathbf{3} \mathbf{b}-\mathbf{d}$, the respective products $4 \mathbf{a}-\mathbf{d}$ and $\mathbf{5 a}-\mathbf{d}$ were isolated in $72-94 \%$. Meanwhile, in reactions with alkylating agents, $\mathbf{3 e} \mathbf{e} \mathbf{j}$ possessing two or three halogen atoms in the benzene ring, afforded complicated mixture of products, so the target compound $4 \mathbf{e}-\mathbf{j}$ and $\mathbf{5 e}-\mathbf{j}$ were isolated in $\mathbf{1 3 - 2 4 \%}$ [25]. All $\mathrm{N}$-phenacylbenzimidazoles $\mathbf{4}-\mathbf{5}$ were purified by column chromatography, followed by crystallization.

Table 1. N-phenacyldibromobenzimidazoles 4-5.

\begin{tabular}{|c|c|c|c|c|c|}
\hline Lp. & $3, \operatorname{Ar} \mathrm{COCH}_{2}, \mathrm{X}$ & $\begin{array}{c}3 / 1 \text { or } 3 / 2 \\
{[\mathrm{~mol} / \mathrm{mol}]}\end{array}$ & $\begin{array}{l}\text { Time of the } \\
\text { Reaction [h] }\end{array}$ & $4[\%]$ & $5[\%]$ \\
\hline 1 & 3a, $\mathrm{Ph}, \mathrm{Br}$ & $1 / 1$ & 24 & $4 a, 94$ & $5 a, 74$ \\
\hline 2 & $3 \mathbf{b}, 4-\mathrm{FC}_{6} \mathrm{H}_{4}, \mathrm{Cl}$ & $1 / 1$ & 24 & $4 b, 81$ & $5 \mathbf{b}, 79$ \\
\hline 3 & $3 \mathrm{c}, 4-\mathrm{ClC}_{6} \mathrm{H}_{4}, \mathrm{Br}$ & $1 / 1$ & 24 & $4 c, 83$ & $5 c, 72$ \\
\hline 4 & $3 \mathrm{~d}, 4-\mathrm{BrC}_{6} \mathrm{H}_{4}, \mathrm{Cl}$ & $1 / 1$ & 24 & $4 d, 79$ & $5 d, 73$ \\
\hline 5 & $3 \mathbf{e}, 2,4-\mathrm{Cl}_{2} \mathrm{C}_{6} \mathrm{H}_{3}, \mathrm{Cl}$ & $2 / 1$ & 3 & $4 e, 17$ & $5 \mathbf{e}, 21$ \\
\hline 6 & 3f, $3,4-\mathrm{Cl}_{2} \mathrm{C}_{6} \mathrm{H}_{3}, \mathrm{Cl}$ & $2 / 1$ & 3 & $4 f, 13$ & $5 f, 15$ \\
\hline 7 & $3 \mathrm{~g}, 2,4,6-\mathrm{Cl}_{3} \mathrm{C}_{6} \mathrm{H}_{2}, \mathrm{Cl}$ & $2 / 1$ & 96 & $4 g, 14$ & $5 g, 15$ \\
\hline 8 & $3 \mathrm{~h}, 2,4-\mathrm{F}_{2} \mathrm{C}_{6} \mathrm{H}_{3}, \mathrm{Cl}$ & $2 / 1$ & 3 & $4 h, 21$ & $5 \mathrm{~h}, 22$ \\
\hline 9 & $3 \mathbf{i}, 2,5-\mathrm{F}_{2} \mathrm{C}_{6} \mathrm{H}_{3}, \mathrm{Cl}$ & $2 / 1$ & 3 & $4 i, 16$ & $5 \mathbf{i}, 17$ \\
\hline 10 & $3 \mathbf{j}, 2,4,6-\mathrm{F}_{3} \mathrm{C}_{6} \mathrm{H}_{2}, \mathrm{Cl}$ & $2 / 1$ & 3 & $4 \mathbf{j}, 23$ & $5 \mathbf{j}, 24$ \\
\hline
\end{tabular}


<smiles>[R]C(Br)=[R][R](=[R])[H]</smiles>

Scheme 1. N-phenacyldibromobenzimidazoles 4-5.

\subsection{The Antifungal Effect of Dibromobenzimidazole Derivatives}

As it is shown in Table 2 and Figures S1-S12 (in Supplementary file), in our initial screening of twenty dibromobenzimidazole derivatives we assessed the percentage of cell growth inhibition (\%I). At the inhibitory concentration of $50 \%\left(\mathrm{IC}_{50}\right)$, the concentration of benzimidazoles that reduces the cell growth of C. albicans SC5314 by $\geq 50 \%$ was determined. Secondly, randomly selected (5f) and the most effective inhibitors (5e and $5 \mathbf{h}$ ) were tested against the C. albicans SPZ176 isolate resistant to Flu and Itr (Table 2). Further, 5e displayed $\mathrm{IC}_{50}$ at $4-16 \mu \mathrm{g} / \mathrm{mL}$ (Table 2) and the mode of fungicidal action against SC5314 at $8-16 \mu \mathrm{g} / \mathrm{mL}(\lg \mathrm{R} \leq 1.19$ in Table 3$)$. 5 f showed $\lg \mathrm{R}=1$ at $8 \mu \mathrm{g} / \mathrm{mL}$ (Table 3). Contrariwise, $\mathbf{5 h}$ displayed no candidacidal action ( $\lg \mathrm{R} \leq 0.43$ in Table 3). Moreover, a paradoxical growth phenomenon of the reference strain SC5314 [26] was noted for the following derivatives: $\mathbf{4 f}, \mathbf{4 h}, \mathbf{5 a}$, and $\mathbf{5 g}-\mathbf{i}$ (Figures S5, S7, S9, S11 and S12) as well as $\mathbf{5 b}$, $\mathbf{5 e}-\mathbf{f}, \mathbf{5 h}, \mathbf{5 j}$ (Table 2). Briefly, we noted a slow decrease in the viable cell growth at higher concentrations (e.g., $\% \mathrm{I}=53 \pm 8$ at $16 \mu \mathrm{g} / \mathrm{mL}$ for $5 \mathbf{b}$ ) vs. the lowest concentrations at which the cell growth was substantially inhibited (e.g., $\% \mathrm{I}=95 \pm 8$ at $8 \mu \mathrm{g} / \mathrm{mL}$ for $5 \mathbf{b}$ ).

Table 2. In vitro antifungal activity of dibromobenzimidazole derivatives against C. albicans ATCC SC5314 and the randomly selected potential antifungals against C. albicans SPZ176 after $48 \mathrm{~h}$.

\begin{tabular}{ccccc}
\hline \multirow{2}{*}{ Candida albicans } & $\begin{array}{c}\text { Comp. } \\
{[\boldsymbol{\mu g} / \mathbf{m L}]}\end{array}$ & \multicolumn{3}{c}{ Cell Growth Inhibition (\%) } \\
\cline { 3 - 5 } & $\mathbf{4 a}$ & $0 \pm 0$ & $\mathbf{8}$ & $\mathbf{1 6}$ \\
\hline & $\mathbf{4 j}$ & $0 \pm 1$ & $20 \pm 2$ & $18 \pm 1$ \\
& $\mathbf{5 b}$ & $0 \pm 2$ & $95 \pm 8^{\mathrm{a}}$ & $53 \pm 8^{\mathrm{a}}$ \\
& $\mathbf{5}$ & $0 \pm 10$ & $0 \pm 1$ & $76 \pm 1^{\mathrm{a}}$ \\
ATCC SC5314 & $\mathbf{5}$ & $71 \pm 1^{\mathrm{a}}$ & $58 \pm 1^{\mathrm{a}}$ & $51 \pm 1^{\mathrm{a}}$ \\
& $\mathbf{5 f}$ & $0 \pm 1$ & $46 \pm 2$ & $37 \pm 1$ \\
& $\mathbf{5 h}$ & $0 \pm 5$ & $81 \pm 4^{\mathrm{a}}$ & $75 \pm 11^{\mathrm{a}}$ \\
& $\mathbf{5 j}$ & $0 \pm 3$ & $83 \pm 1^{\mathrm{a}}$ & $0 \pm 3$ \\
& $\mathrm{AmB}$ & $100 \pm 1$ & $100 \pm 2$ & $100 \pm 1$ \\
\hline Isolate SPZ176 & $\mathbf{5 e}$ & $0 \pm 0.0$ & $17 \pm 7$ & $80 \pm 8^{\mathrm{a}}$ \\
& $\mathbf{5 f}$ & $0 \pm 10$ & $0 \pm 4$ & $94 \pm 5^{\mathrm{a}}$ \\
& $\mathbf{5 h}$ & $0 \pm 7$ & $0 \pm 2$ & $100 \pm 3^{\mathrm{a}}$ \\
& $\mathrm{AmB}$ & $100 \pm 2$ & $100 \pm 1$ & $100 \pm 1$ \\
\hline
\end{tabular}

Legend: ${ }^{a}$ inhibitory concentration of $\mathrm{IC}_{50}$ (concentration resulting in the cell growth inhibition by $\geq 50 \%$ ) at $405 \mathrm{~nm}$ using spectrophotometric measurement SPE (SPARK Tecan Group. Austria) [27]; Amphotericin B (AmB) as positive control; Ref. C. albicans SC5314 from American Type Culture Collection (ATCC) and clinical strain SPZ176 (resistant to fluconazole Flu and itraconazole Itr) were tested. Data represent mean \pm SD, $n=3$. 
Table 3. Logarithmic cell growth reduction factor (R) of C. albicans ATCC SC5314.

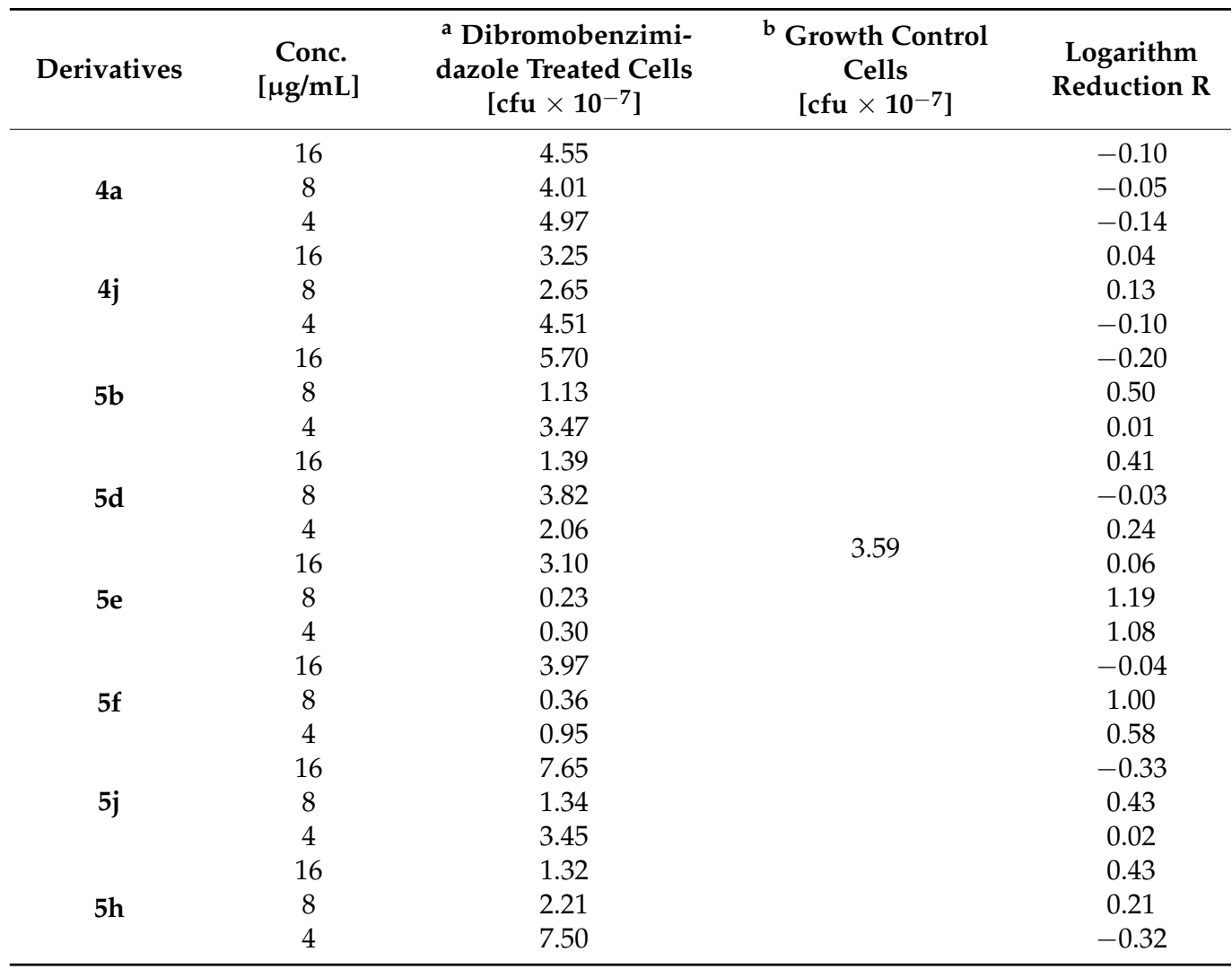

Legend: ${ }^{a} \mathrm{cfu}$ of $C$. albicans after treatment with dibromobenzimidazole at a proper concentration, ${ }^{\mathrm{b}} \mathrm{cfu}$ of untreated inoculum of $C$. albicans. Decrease is expressed as decimal $\log$ reduction using formula $\lg R=\lg \mathrm{cfu} / \mathrm{mL}$ control cells $-\lg \mathrm{cfu} / \mathrm{mL}$ benzoxazole treated cells. Dibromobenzimidazole reducing C. albicans cells at least for $\lg \mathrm{R} \geq 1$ was defined as fungicidal. Data represent mean $\pm \mathrm{SD}, n=2$.

Table 4. Recovery of the colony forming units of the fungal isolates after 48 h-treatment with $N$-phenacyldibromobenzimidazole.

\begin{tabular}{|c|c|c|c|}
\hline Comp. & $\begin{array}{c}\text { Conc. } \\
{[\mu \mathrm{g} / \mathrm{mL}]}\end{array}$ & $\begin{array}{c}\text { C. albicans } \\
{[\mathrm{cfu} / \mathrm{mL}]}\end{array}$ & $\begin{array}{l}\text { C. neoformans } \\
\text { [cfu/mL] }\end{array}$ \\
\hline \multirow{3}{*}{$5 e$} & 4 & \multirow{12}{*}{$10^{5}$} & $10^{5}$ \\
\hline & 8 & & $7 \times 10^{2}$ \\
\hline & 16 & & $10^{5}$ \\
\hline \multirow{3}{*}{$5 f$} & 4 & & $10^{4}$ \\
\hline & 8 & & $10^{4}$ \\
\hline & 16 & & $10^{4}$ \\
\hline \multirow{3}{*}{$5 \mathrm{~h}$} & 4 & & $10^{4}$ \\
\hline & 8 & & 0 \\
\hline & 16 & & 0 \\
\hline \multirow{3}{*}{$A m B$} & 4 & & 0 \\
\hline & 8 & & 0 \\
\hline & 16 & & 0 \\
\hline
\end{tabular}

Legend: the clinically derived strains: C. albicans SPZ176 and C. neoformans SPZ173 (naturally resistant to echinocandins). Amphotericin B (AmB) as positive control. 0 means no cfu recovery $[27,28]$. Data represent mean $\pm \mathrm{SD}, n=2$.

We determined the effectiveness of dibromobenzimidazole derivatives against the fungal isolates using colony forming unites (cfu) assay (Table 4). The exhaustive data clearly demonstrated that cfu were recovered after treatment with the tested dibromobenzimidazoles (Table 4). The most effective $5 \mathrm{~h}$ at $16 \mu \mathrm{g} / \mathrm{mL}$ totally inhibited recovery of cfu of both clinical isolates. In the case of $C$. neoformans, there was no cfu recovery after treatment with $5 \mathrm{~h}$ at the concentration range of $8-16 \mu \mathrm{g} / \mathrm{mL}$. Thus, $C$. neoformans was more sensitive 
to $5 \mathrm{~h}$ than C. albicans. We identified the leading fungicidal compound $5 \mathrm{~h}$ to be used in a series of follow-up analyses to establish its action mode in vitro.

\subsection{Cytotoxicity of N-Phenacyldibromobenzimidazole Derivatives}

As it was shown in Figure 1, the Vero cell viability or cytotoxicity generated by the most active compounds (fungicidal) was assessed using the MTS method. Figure 1 indicates $\mathrm{CC}_{50}=32-64 \mu \mathrm{g} / \mathrm{mL}$ and $\mathrm{CC}_{90}=64-256 \mu \mathrm{g} / \mathrm{mL}$ for $\mathbf{5 e}$ and $\mathbf{5 f}$. Moreover, $5 \mathbf{h}$ displayed $\mathrm{CC}_{50}=32-64 \mu \mathrm{g} / \mathrm{mL}$ and $\mathrm{CC}_{90}=256 \mu \mathrm{g} / \mathrm{mL}$. Thus, all compounds did not inhibit the $\mathrm{NAD}(\mathrm{P}) \mathrm{H}$ dehydrogenase (quinone) activity and disturb cell membrane permeability.

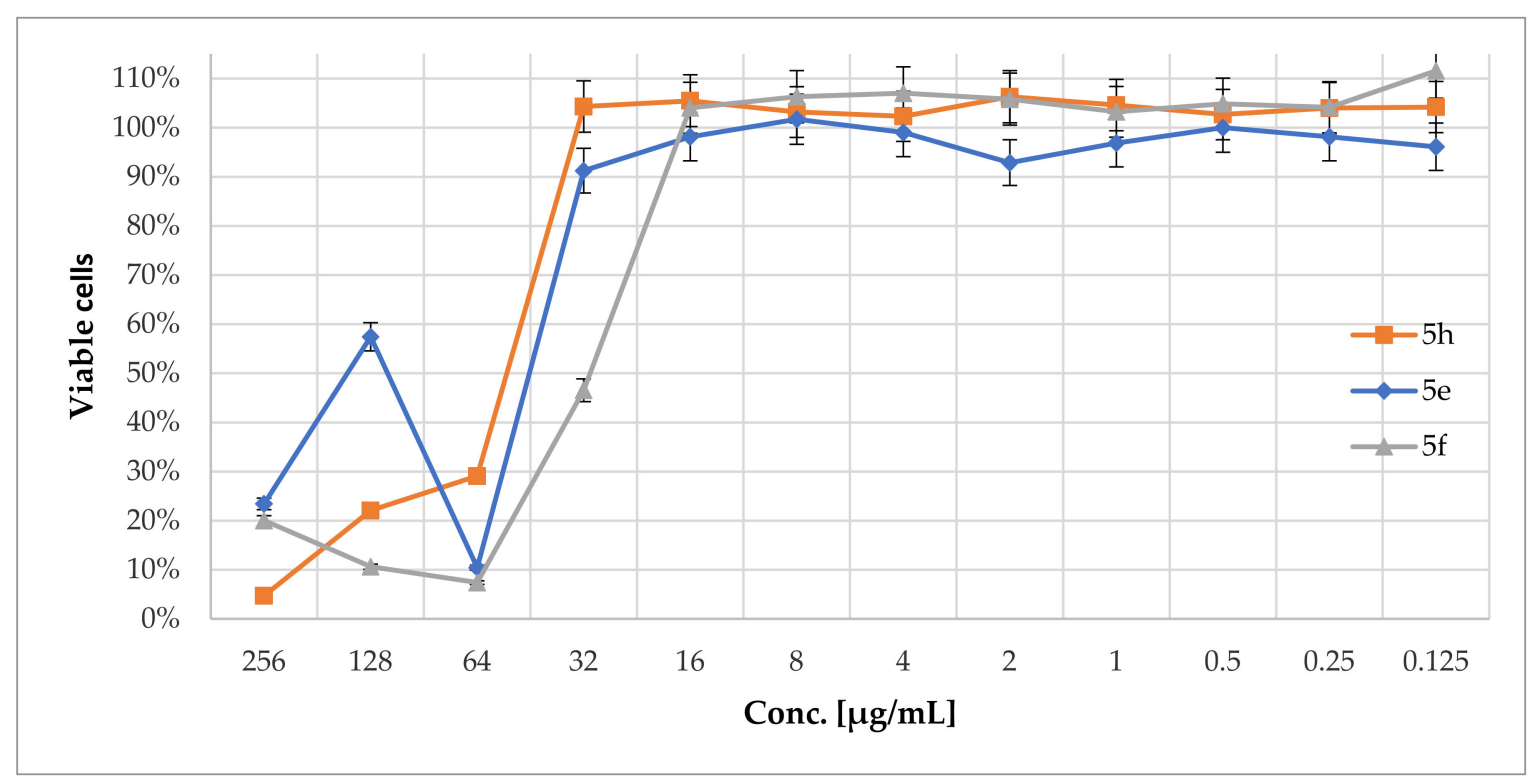

Figure 1. Viability of the Vero cells treated with $N$-phenacyldibromobenzimidazole derivatives. Legend: Range of conc. of $5 \mathbf{e}-\mathbf{f}$ and $5 \mathbf{h}$ where $\mathrm{CC}_{50}$ and $\mathrm{CC}_{90}$ were noted against the Vero cells: $\mathrm{CC}_{50}=32-64 \mu \mathrm{g} / \mathrm{mL}$ and CC $90=64-256 \mu \mathrm{g} / \mathrm{mL}$ for $5 \mathbf{e}-\mathbf{f} ; \mathrm{CC}_{50}=32-64 \mu \mathrm{g} / \mathrm{mL}$ and $\mathrm{CC}_{90}=256 \mu \mathrm{g} / \mathrm{mL}$ for $5 \mathbf{h}$. Values are presented as means \pm standard deviation. Data represent mean $\pm \mathrm{SD}, n=3$.

\subsection{Antifungal Activity of $\mathbf{5 h}$ in Combination with Osmoprotectant}

The $\% \mathrm{I}$ values of $\mathbf{5 h}$ were changed in the presence of sorbitol, and it suggests influence of $5 \mathbf{h}$ on the cell wall structure of the C. albicans clinical isolate (Table 5). In details, $\mathbf{5 h}$ displayed lack or weak $(\% \mathrm{I}=8 \pm 18)$ cell growth inhibition at $16 \mu \mathrm{g} / \mathrm{mL}$ in the presence of $0.8 \mathrm{M}$ sorbitol as an osmotic protectant in the medium vs. one without sorbitol ( $\% \mathrm{I}=100 \pm 3$ in Table 2$)$. For the $C$. neoformans isolate, the antifungal activity of $5 \mathbf{h}$ was as follows: (1) $5 \mathrm{~h}$ at $4 \mu \mathrm{g} / \mathrm{mL}$ causes no cell growth inhibition in medium with sorbitol added vs. $1 \times 10^{5} \mathrm{cfu} / \mathrm{mL}$ recovered in medium without sorbitol (Table 4); (2) $5 \mathbf{h}$ displays no growth recovery at $8-16 \mu \mathrm{g} / \mathrm{mL}$ in medium without sorbitol vs. $\% \mathrm{I}=79-95$ at the same range of concentrations in medium with sorbitol added. 
Table 5. Antifungal activity of $\mathbf{5 h}$ against the clinical isolates in sorbitol as osmotic protector.

\begin{tabular}{cccc}
\hline \multirow{2}{*}{ Strains } & $\begin{array}{c}\text { Conc. } \\
{[\boldsymbol{\mu g} / \mathbf{m L}]}\end{array}$ & \multicolumn{2}{c}{ Growth Inhibition [\% $\pm \mathbf{S D}]$} \\
\cline { 3 - 4 } & 4 & $\mathbf{9 6} \mathbf{~ h}$ & $\mathbf{1 2 0 ~ \mathbf { ~ }}$ \\
\hline \multirow{3}{*}{ C. neoformans SPZ173 } & 8 & 0 & 0 \\
& 16 & $93 \pm 15$ & $79 \pm 9$ \\
\hline \multirow{3}{*}{ C. albicans SPZ176 } & 4 & $95 \pm 26$ & $86 \pm 15$ \\
& 8 & 0 & 0 \\
& 16 & 0 & $8 \pm 18$ \\
\hline
\end{tabular}

Legend: data presented as mean $\% \pm$ RSD $\%$, cells were incubated with $5 \mathbf{h}$ for 96 and $120 \mathrm{~h} ; 0$ means no cell growth inhibition. Data represent mean $\pm \mathrm{SD}, n=3$.

\subsection{Chitinolytic Activity of $\mathbf{5 h}$}

As it was shown in Table 6, the detailed studies on chitinolytic activity showed affinity of $5 \mathrm{~h}$ to the following substrates: 4-nitrophenyl- $N$-acetyl- $\beta$-D-glucosaminide and 4-nitrophenyl- $N, N^{\prime}$-diacetyl- $\beta$-D-chitobioside. Contrariwise, $5 \mathbf{h}$ displayed no affinity to 4-nitrophenyl- $\beta-\mathrm{D}-N, N^{\prime}, N^{\prime \prime}$-triacetylchitothiose.

Table 6. Chitinolytic activity $[\mathrm{U} / \mathrm{mL}]$ of $5 \mathrm{~h}$.

\begin{tabular}{cccc}
\hline \multirow{2}{*}{ Substrate } & \multicolumn{3}{c}{$\mathbf{U} \mathbf{m} \times \mathbf{1 0}^{\mathbf{5}}$} \\
\cline { 2 - 4 } & $\mathbf{A}$ & $\mathbf{B}$ & $\mathbf{C}$ \\
\hline $\mathbf{5 h}$ & 21 & 0 & 21 \\
Chitinase & 3140 & 3560 & 3360 \\
\hline
\end{tabular}

Legend: Three substrates were used: A (4-nitrophenyl- $N$-acetyl- $\beta$-D-glucosaminide), B (4-nitrophenyl- $\beta$-D$N, N^{\prime}, N^{\prime \prime}$-triacetylchitothiose), C (4-nitrophenyl- $N, N^{\prime}$-diacetyl- $\beta$-D-chitobioside). Lack of chitinolytic activity was concluded if the equation yielded a value lower than one $\mathrm{U} / \mathrm{mL}$. The equation was used as Equation (1). Data represent mean $\pm \mathrm{SD}, n=3$.

\subsection{Efflux Disorder under $\mathbf{5 h}$}

Rho123 was not able to leave the mitochondrion due to the membrane potential decreased (efflux decreased) as a results of cell death. For the C. albicans ref. strain and C. neoformans isolate, efflux decreased in line with increased conc. of $5 \mathbf{h}$ (Table 7). Contrariwise, in the case of C. albicans clinical isolate, efflux was noted for the 5 h-treated cells at $16 \mu \mathrm{g} / \mathrm{mL}$ (Table 7).

Table 7. Decrease of rhodamine content $[\Delta \mathrm{C} \% \pm \mathrm{RSD} \%]$.

\begin{tabular}{cccc}
\hline 5h $[\mu \mathrm{g} / \mathrm{mL}]$ & C. albicans SC5314 & C. albicans SPZ176 & $\begin{array}{c}\text { C. neoformans } \\
\text { SPZ173 }\end{array}$ \\
\hline 160 & $4 \pm 9$ & $0 \pm 0$ & $15 \pm 2$ \\
16 & $6 \pm 2$ & $6 \pm 1$ & $14 \pm 4$ \\
4 & $0 \pm 1$ & $0 \pm 5$ & $18 \pm 8$ \\
\hline
\end{tabular}

Legend: Concentration of Rho123 in the postgrowth medium of the $\mathbf{5 h}$-treated cells vs. the untreated control $\Delta \mathrm{C} \%=[\mathrm{C}($ Test $)-\mathrm{C}($ Control $)] / \mathrm{C}(\mathrm{Control}) \times 100$; where: $\mathrm{C}($ Test $)-$ concentration of Rho123 in the tested samples; $\mathrm{C}(\mathrm{Control})$ - concentration of Rho123 in the untreated control. Data represent mean $\pm \mathrm{SD}, n=3$.

\subsection{Compound $5 \mathbf{h}$ Induces ROS Generation}

Treatment of the fungal cells with low concentration of $5 \mathrm{~h}$ led to the ROS production at high level (198\%In Figure 2). Generally, in the case of C. neoformans, the level of ROS production increased in line with decreasing concentrations of $\mathbf{5 h}$. Remaining strains showed ROS under detectable level, with exception of C. albicans SPZ176 generating ROS at $22 \%$ under treatment with $5 \mathrm{~h}$ at $4 \mu \mathrm{g} / \mathrm{mL}$. 


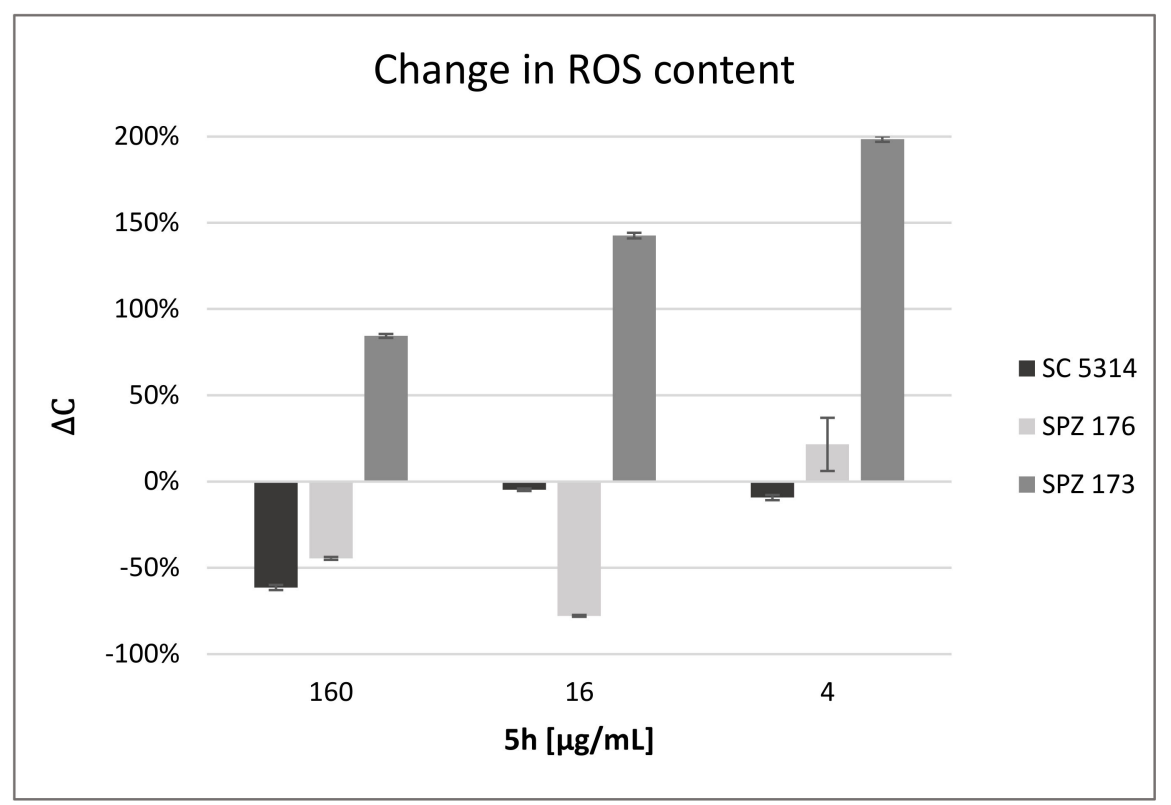

Figure 2. Change in ROS content in fungal strains treated with $5 \mathbf{h}$. Legend: $\Delta C=[E(T e s t)-$ $\mathrm{E}(\mathrm{Control})] \times 100 \% / \mathrm{E}(\mathrm{Control})$; where $\Delta \mathrm{C}$ - change in the ROS content; $\mathrm{E}($ Test $)$ - fluorescence of test samples; $\mathrm{E}$ (Control) - fluorescence of negative control [29,30]. C. albicans SC5314, C. albicans SPZ176 and C. neoformans SPZ173 treated with $5 \mathrm{~h}$ compared to the untreated control. Values are presented as means \pm relative standard deviation. Data represent mean $\pm \mathrm{SD}, n=3$.

\subsection{Estimation of Accidental Cell Death in the $\mathbf{5 h}$-Treated Fungi}

As shown in Figures 3 and $4,5 \mathrm{~h}$ at the concentrations ranging from 4 to $160 \mu \mathrm{g} / \mathrm{mL}$ generated necrosis (accidental cell death ACD) in the fungal cells and protoplasts. Apoptosis early or late was induced approx. at $0.31 \%$ or $0.83 \%$ in the C. albicans protoplasts under treatment with $5 \mathrm{~h}$ at $160 \mu \mathrm{g} / \mathrm{mL}$. In the case of $C$. neoformans, apoptosis was generated approx. at $0.04 \%$ (early) and $0.02 \%$ (late) by $5 \mathrm{~h}$ at $160 \mu \mathrm{g} / \mathrm{mL}$. In the case of the C. neoformans protoplasts, late apoptosis was noted approx. at $0.03 \%$ or $0.02 \%$, respectively, for 160 or $16 \mu \mathrm{g} / \mathrm{mL}$. 


\section{C. albicans SPZ 176}

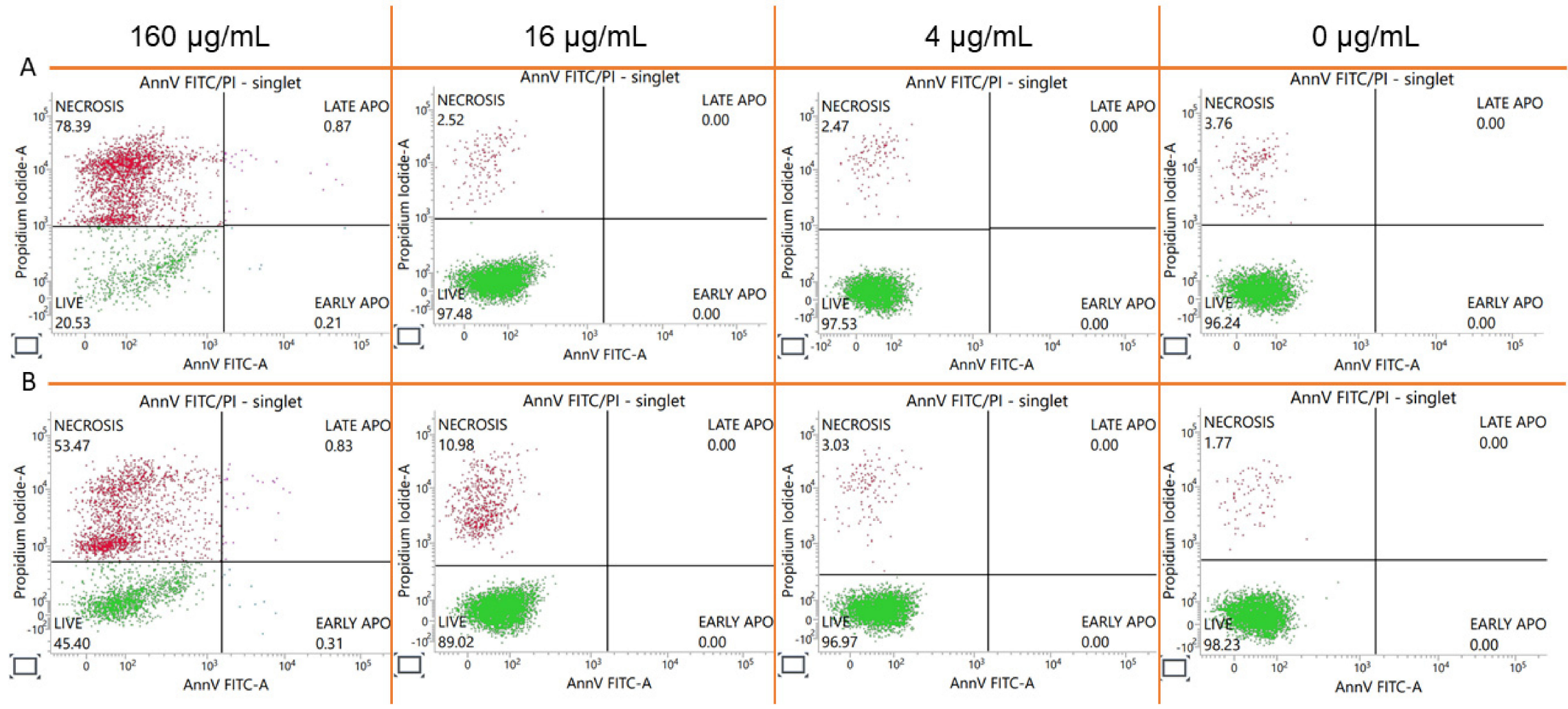

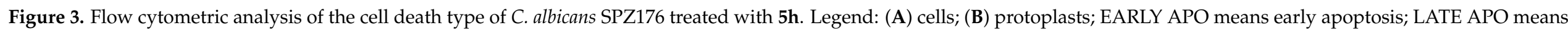
late apoptosis. Data represent mean $\pm \mathrm{SD}, n=3$. 
C. neoformans SPZ 173

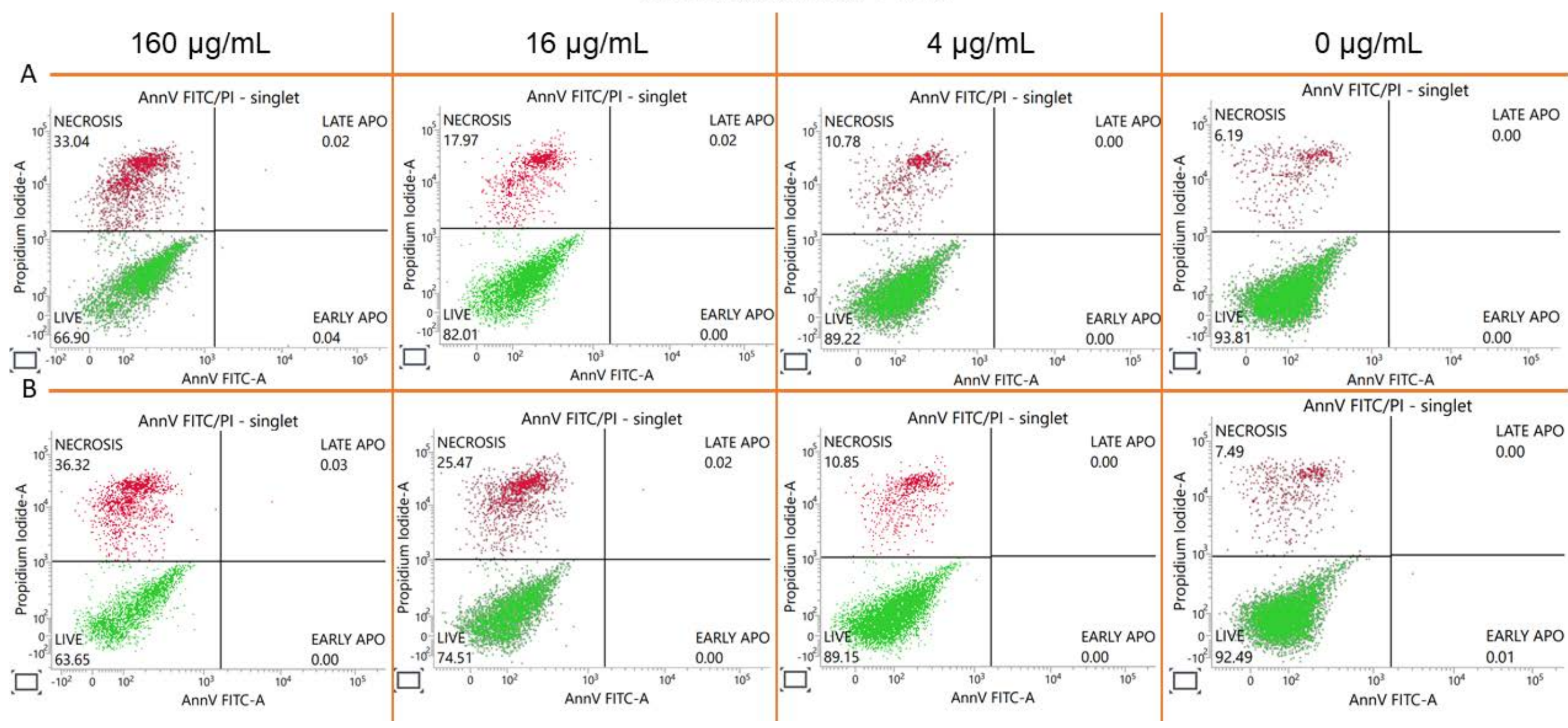

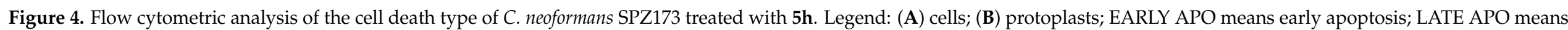
late apoptosis. Data represent mean $\pm \mathrm{SD}, n=3$. 


\subsection{Antifungal Action and Accidental Cell Death by Fluorescent Structural Staining Techniques}

The resulting cell wall damage and cell viability were assessed using Confocal laser scanning microscopy (CLSM) after treatment with $5 \mathbf{h}$ (twelve images were assessed for each treatment/staining). As it was shown using CFW staining (Figure 5), $5 \mathbf{h}$ at $16 \mu \mathrm{g} / \mathrm{mL}$ induced the cell wall rearrangement of the $C$. albicans sessile conglomerate. Biofilm's chitin content was redistributed and elevated under treatment with $5 \mathrm{~h}$ (vivid blue fluorescence of elevated chitin in Figure 5). Contrariwise, action of $5 \mathrm{~h}$ against the $C$. neoformans sessile growth was not significant (Figure 6). In Figure 6, very few cells were totally stained with CFW in conglomerate vs. the untreated control showing several cells with bright blue fluorescence. Thus $5 \mathrm{~h}$ did not reorganize the cell wall chitin content of $C$. neoformans.

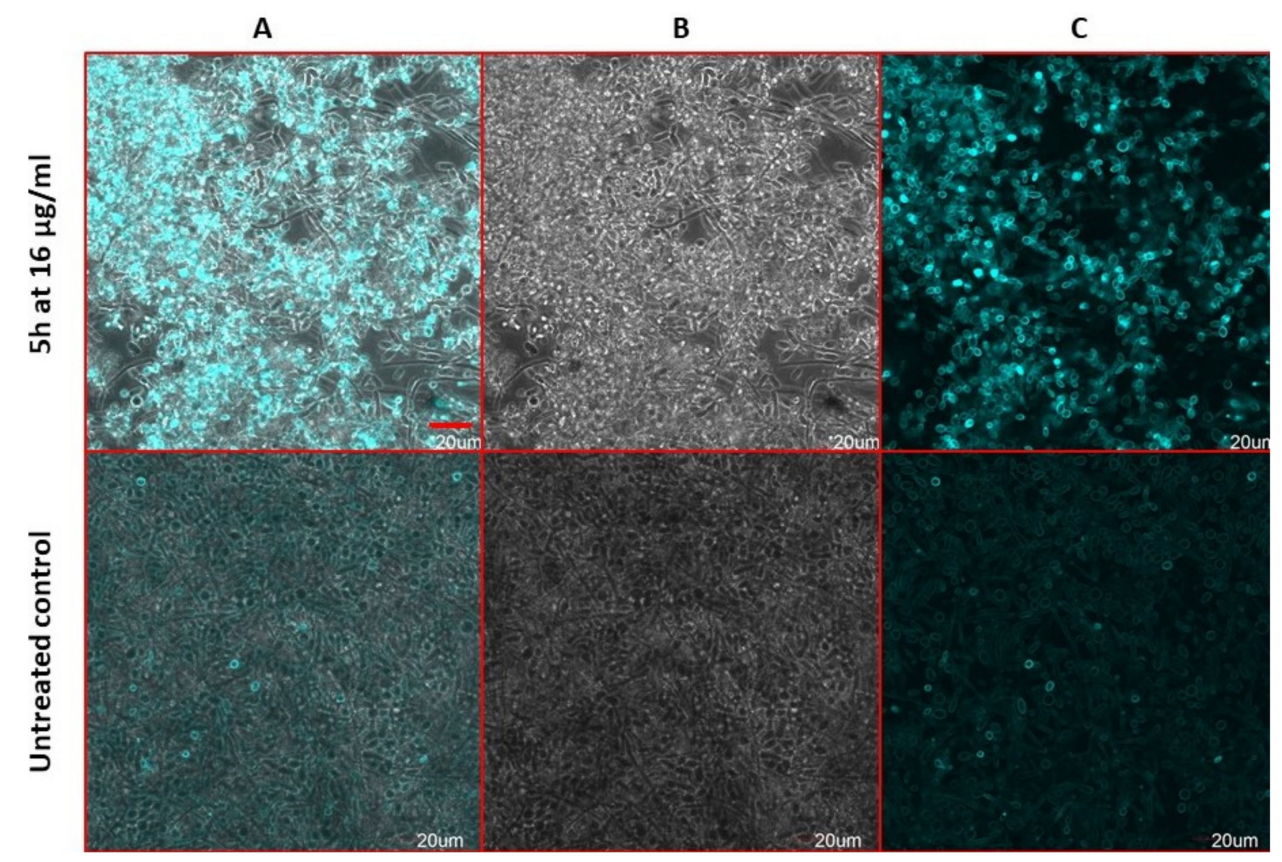

Figure 5. The fluorescent staining of the C. albicans SPZ176 biofilm with calcofluor white (CFW). Legend: Confocal laser scanning microscope (CLSM) analyses: (A) phase contrast and fluorescence merged; (B) phase contrast and (C) fluorescence images. (A-C) Upper raw depicts sessile cells treated with $5 \mathrm{~h}$ at $16 \mu \mathrm{g} / \mathrm{mL}$; lower raw included the untreated controls. Sessile cells stained with calcofluor white (CFW) at final concentration of $2.5 \mu \mathrm{g} / \mathrm{mL}$ showed vivid blue fluorescence of elevated chitin in the $5 \mathbf{h}$-treated morphotypes (upper raw). Reduced fluorescence of chitin in the intact untreated control sessile cells was noted (lower raw).

Congo red (CR) interacts with $\beta$-D-glucan of the 5 h-treated C. albicans sessile cells (Figure 7). Thus, the cells exposed to $5 \mathrm{~h}$ at $16 \mu \mathrm{g} / \mathrm{mL}$ exhibit increased frequencies of the cell wall damage (arrows in Figure 7). Contrariwise, the biofilm of $\boldsymbol{C}$. neoformans treated with $5 \mathrm{~h}$ was found CR sensitive in comparable level to the untreated sessile cells (Figure 8). Thus $5 \mathrm{~h}$ did not disturb the glucan content of $C$. neoformans. 


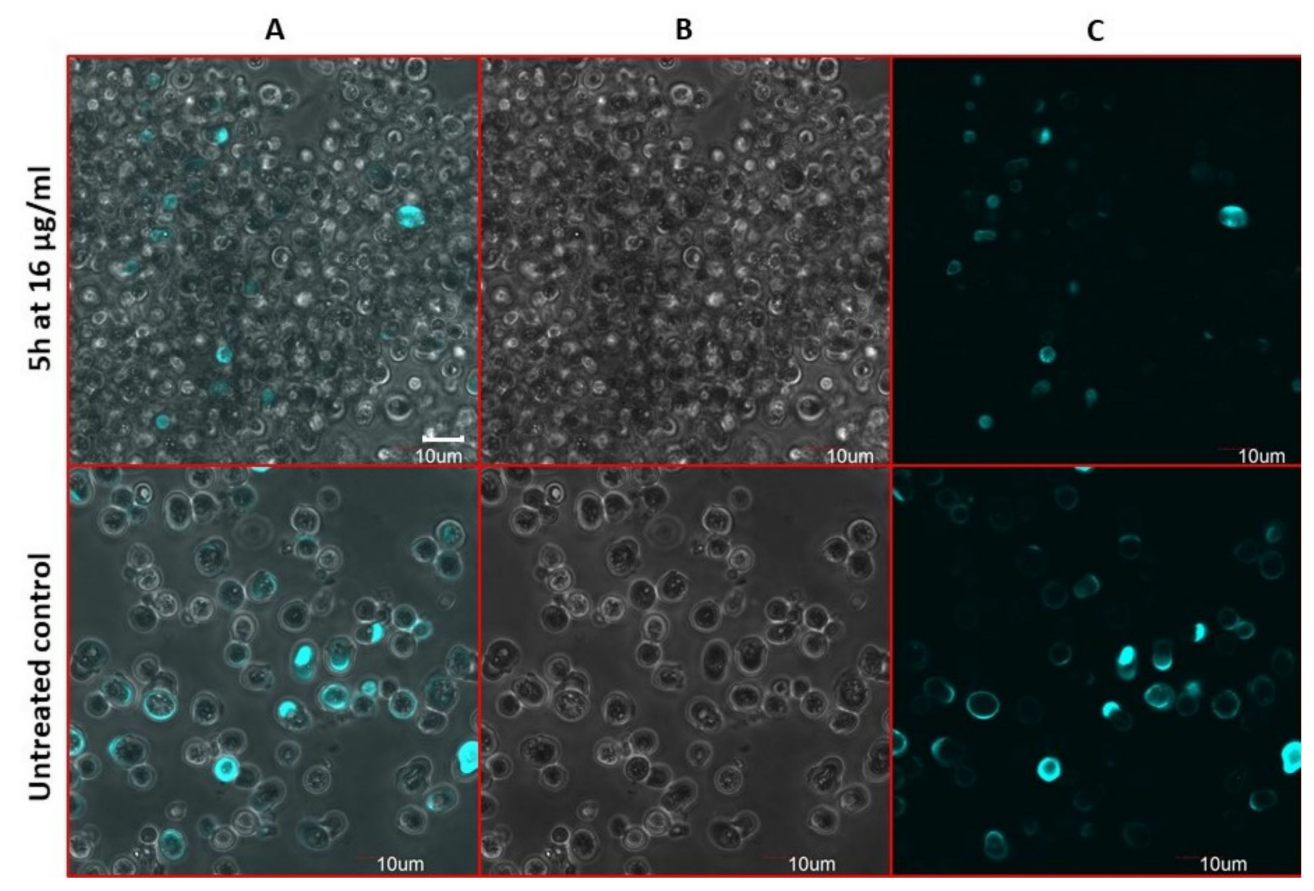

Figure 6. The fluorescent staining of the C. neoformans SPZ173 biofilm with calcofluor white (CFW). Legend: Confocal laser scanning microscope (CLSM) analyses: (A) phase contrast and fluorescence merged; (B) phase contrast and (C) fluorescence images. (A-C) Upper raw depicts sessile cells treated with $5 \mathrm{~h}$ at $16 \mu \mathrm{g} / \mathrm{mL}$. Sessile cells-treated with $5 \mathrm{~h}$ showed weak CFW staining. Lower raw included the untreated controls showing several cells with bright blue fluorescence.

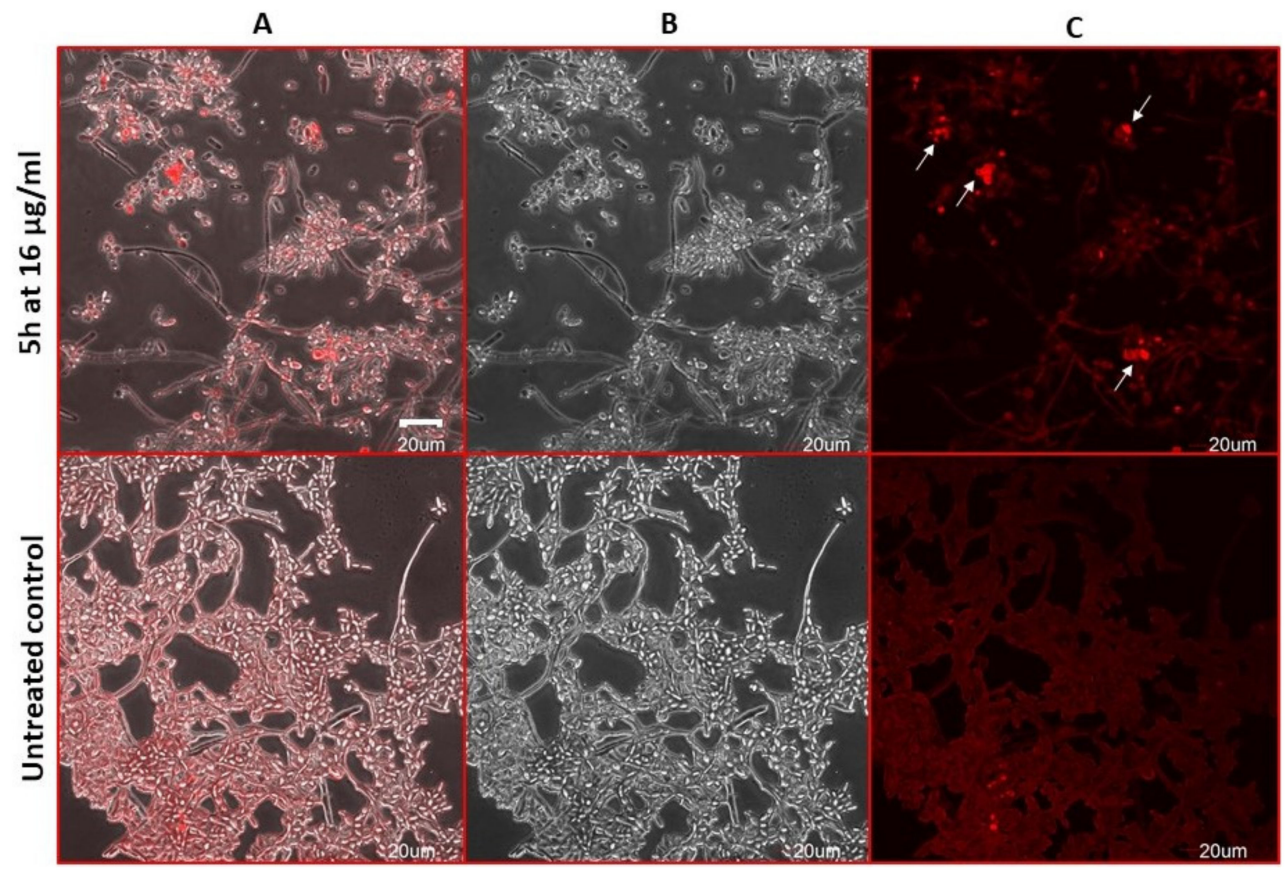

Figure 7. Congo red (CR)-stained C. albicans SPZ176 sessile growth. Legend: Confocal laser scanning microscope (CLSM) analyses: (A) phase contrast and fluorescence merged; (B) phase contrast and (C) fluorescence images. (A-C) Upper raw depicts elevated beta-glucan CR-stained (arrows) in several cells in the conglomerate of sessile growth treated with $5 \mathrm{~h}$ at $16 \mu \mathrm{g} / \mathrm{mL}$. Lower raw included the untreated controls showing lack of CR staining. 


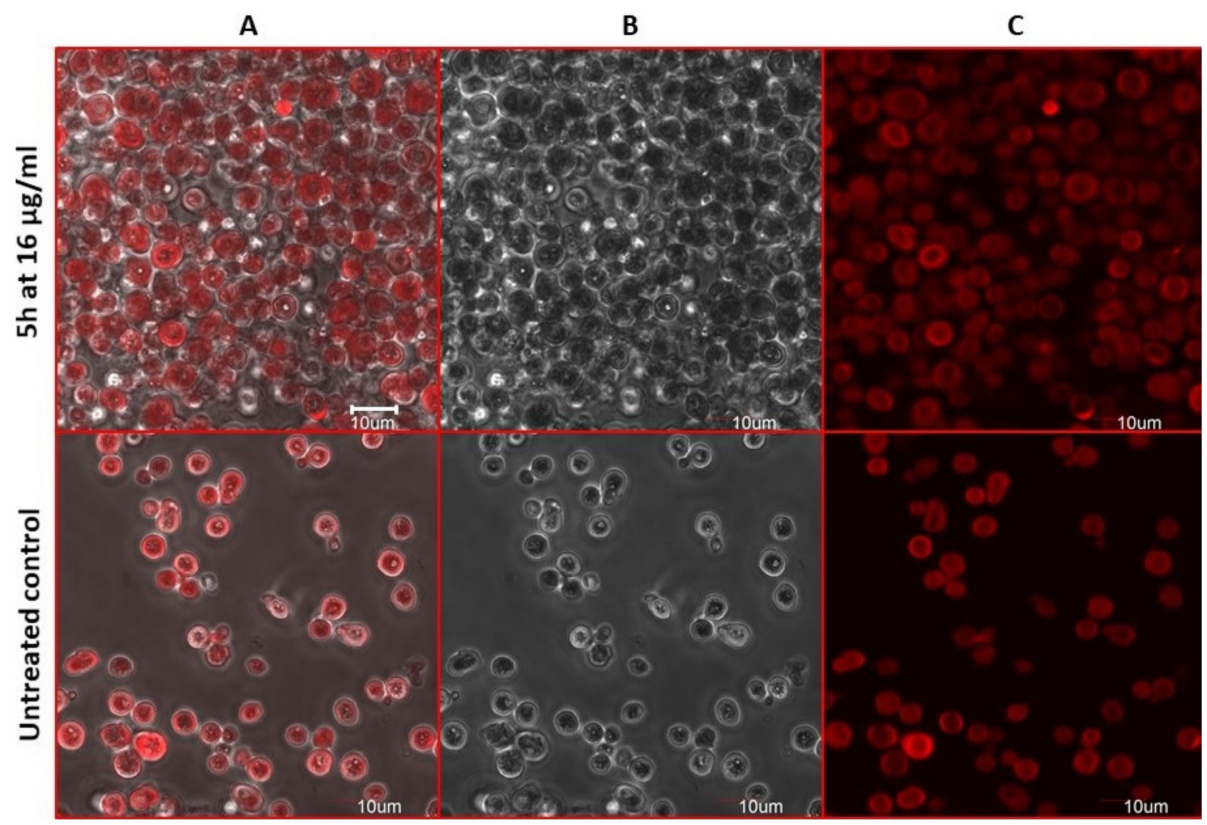

Figure 8. The C. neoformans SPZ173 sessile growth stained with Congo red (CR). Legend: Confocal laser scanning microscope (CLSM) analyses: (A) phase contrast and fluorescence merged; (B) phase contrast and (C) fluorescence images. (A-C) Upper raw depicts beta-glucan CR-stained in the conglomerate of sessile cells treated with $5 \mathrm{~h}$ at $16 \mu \mathrm{g} / \mathrm{mL}$. Lower raw included the untreated controls showing CR staining.

Compound $\mathbf{5 h}$ altered plasma membrane permeability, which is indicated by intensive red fluorescence of the 5 h-treated sessile cells (Figure 9), compounds induced necrosis-like cell death (bright red fluorescence of ethidium bromide EB inside the damaged sessile cells in Figure 9). Contrariwise, C. neoformans was resistant to $\mathbf{5 h}$ (arrows indicate weak green fluorescence of acridine orange AO inside the viable cells in Figure 10).

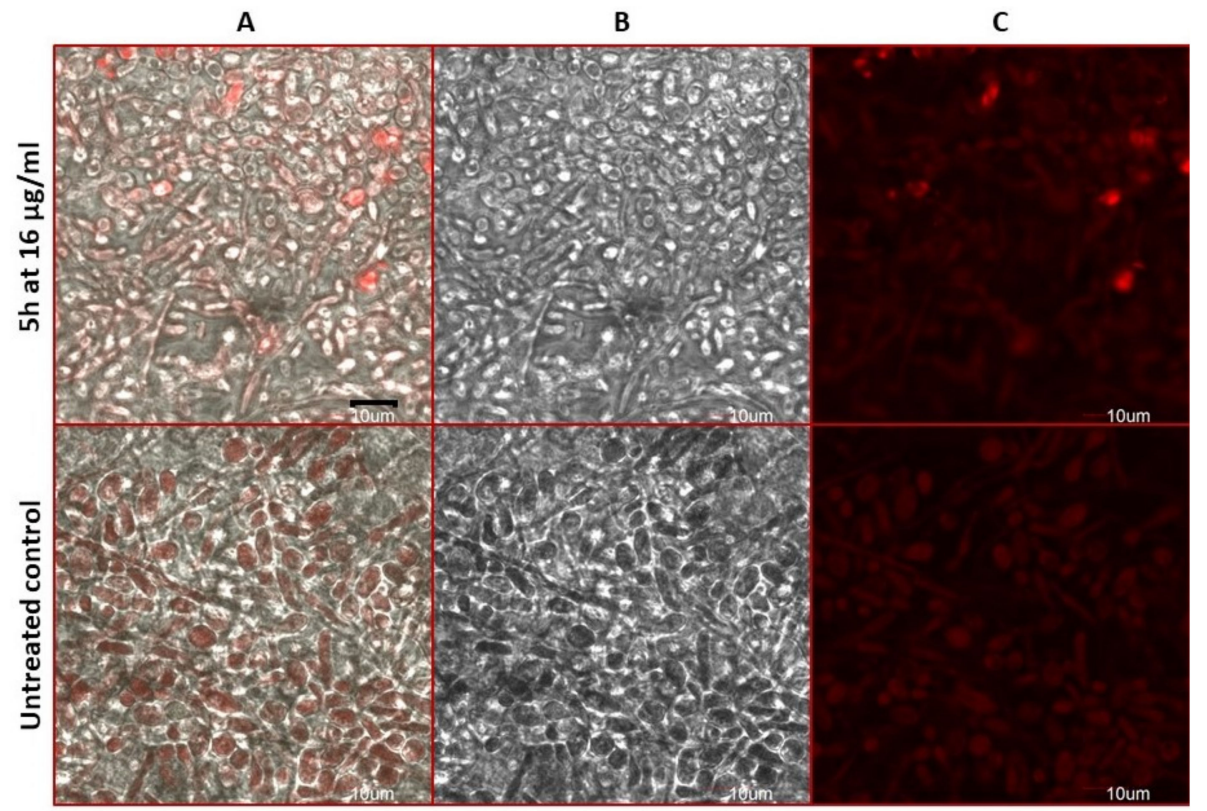

Figure 9. The C. albicans SPZ 176 sessile cell-death assessment. Legend: Confocal laser scanning microscope (CLSM) analyses of acridine orange (AO)- and ethidium bromide (EB)-stained biofilm cells. (A) phase contrast and fluorescence merged; (B) phase contrast and (C) fluorescence images. (A-C) Upper raw shows necrotic cells treated with $5 \mathrm{~h}$ at $16 \mu \mathrm{g} / \mathrm{mL}$. Lower raw displays viable untreated control cells without uptaking EB. 


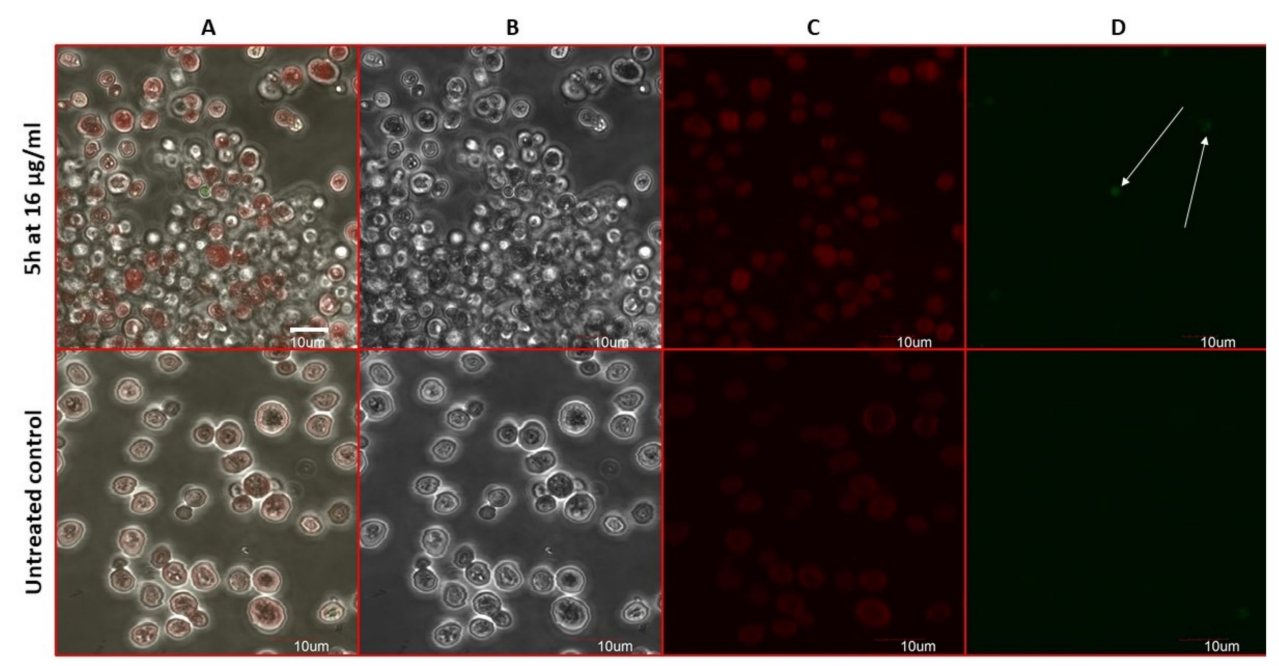

Figure 10. The C. neoformans SPZ173 biofilm-death assessment. Legend: Confocal laser scanning microscope (CLSM) analyses of acridine orange (AO)- and ethidium bromide (EB)-stained biofilm cells. (A) phase contrast and fluorescence merged; (B) phase contrast and (C) fluorescence images. (A-C) Upper raw shows alive cells treated with $5 \mathrm{~h}$ at $16 \mu \mathrm{g} / \mathrm{mL}$. (D) Viable cells appear green with intact nuclei (arrows). Lower raw displays viable untreated control cells.

\section{Discussion}

Antifungal structure-activity relationships showed that the group of 5,6-dibromobenzimidazole derivatives are less active against $C$. albicans vs. 4,6-dibromobenzimidazole analogues (Table 2 and Figures S1-S12 (in Supplementary file)). Moreover, the substitution of chlorine atoms to the benzene ring of the $\mathrm{N}$-phenacyl substituent extended anti-C. albicans activity (5e with $2,4-\mathrm{Cl}_{2}$ or $\mathbf{5 f}$ with $3,4-\mathrm{Cl}_{2}$ in Tables $1-4$ and Table S1 in Supplementary file). Contrariwise, the substitution of bromine or fluorine atoms in the same positions influences weak activity against Candida spp. The findings described above are in line with Vargas-Oviedo et al. [14]. It is worth to mention that $\mathbf{5 h}$ substituted with fluorine atoms at $\mathrm{C} 2$ and $\mathrm{C} 4$ of the benzene ring of the $\mathrm{N}$-phenacyl group exhibited excellent fungicidal activity against the $C$. albicans reference and clinical strain as well as the $C$. neoformans isolate (Tables 2-4). In our study, the leading compound $\mathbf{5 h}$ (Table 4 ) was $<16$-times less active than $\mathrm{AmB}$ with minimal fungicidal concentration $\mathrm{MFC}_{90}=1 \mu \mathrm{g} / \mathrm{mL}$ [31] and $\mathrm{MFC}=0.5$ [32] against the C. albicans isolates and SC5314, respectively. Structure-activity relationships provide opportunities for synthesis of dibromobenzimidazole analogues with improved antifungal action. Moreover, the most active antifungals (5e-f, $5 \mathbf{h})$ at the concentration range of $32-0.125 \mu \mathrm{g} / \mathrm{mL}$ were developed to generate viable and vital eukaryotic cells (Figure 1 and Figure S13; Tables S2 and S3). Thus, the tested dibromobenzimidazole were proved to be less cytotoxic against the Vero cells compared to AmB (toxic at 15-20 $\mu \mathrm{g} / \mathrm{mL}$ after $24 \mathrm{~h}$ ) [33].

In line with the results obtained in the presence of the osmo-protectant in the growth medium [34], we showed that $5 \mathbf{h}$ is the $C$. albicans cell wall inhibitor, displaying reverse effect in the presence of sorbitol (Table 5). The effect is characterized by decreasing in $\% \mathrm{I}$ (Table 5) as observed in the medium with sorbitol vs. medium without protectant (Table 2). Our studies demonstrated that osmotic protector reduces anti-Candida activity of 5h. In alignment with Górska-Nieć et al. [35], we proved that enhanced biomass production leads to loss of antifungal activity of $5 \mathrm{~h}$ at concentrations ranging from 4 to $16 \mu \mathrm{g} / \mathrm{mL}$. Moreover, the activity of $5 \mathrm{~h}$ did not correspond with AmB affecting cell wall due to activity accompanied by an increase concentration in medium with sorbitol [36].

Moreover, the micromorphological evaluation of the C. albicans-treated with $5 \mathrm{~h}$ revealed the lack of structures indicating fungal mycelium typical for biofilm. Thus $5 \mathbf{h}$ was able to inhibit the biofilm formation (Figures 5-10). Since the yeast-hyphae morphological 
transition is relevant for C. albicans virulence [37] we indicated that $5 \mathrm{~h}$ represents promising therapeutic.

We showed that $5 \mathbf{h}$ acts by the cell wall chitin lysis originated from the comparison studies with chitinase (Table 6). Chitin is a polymer of $\beta$-1,4-linked $N$-acetyl-D-glucosamine (GlcNAc), which is an integral component of the fungal cell wall [38]. 5h was able to hydrolase 4-nitrophenyl- $N$-acetyl- $\beta$-D-glucosaminide and 4-nitrophenyl- $\beta$-D- $N, N^{\prime}, N^{\prime \prime}$ triacetylchitothiose without activity against triacetylchitothiose (Table 6). Based on our results and in line with Nielsen and Sörensen [39], we hypothesized that $5 \mathbf{h}$ displays comparable activity to chitinase (EC 3.2.1.14). Since the ability of Congo red CR fluorescent tracker to visualize the fungal cell wall elements was described previously [40,41], we used $\mathrm{CR}$ as a diazo compound pertaining to its high affinity to polysaccharides in the $\mathbf{5 h}$-treated C. albicans $[40,41]$. In line with Shalmy et al. [40] we found good staining result of CR in the 5 h-treated C. albicans vs. 5 h-treated capsule of $C$. neoformans which was poorly stained (Figure 7 vs. Figure 8). We showed that 5 h displayed Candida spp. dependent activity.

Furthermore, $5 \mathrm{~h}$ induced the phosphatidylserine PE translocation and membrane permeability [41], these were shown using the Annexin V and propidium iodide PI staining assay (Figures 3 and 4). We hypothesized that PE externalization affect subsequently the elevated chitin content (Figure 5) and activity of $5 \mathbf{h}$. Moreover, this polymer play an essential role in the sensitivity (or resistance) of C. albicans to AmB [42-44]. Since ROS play a crucial role in intracellular signalling [44], C. neoformans treated with $5 \mathbf{h}$ displayed elevated ROS (Figure 2 and Table S4) regarded as a cell death phenotype in connection with plasma membrane disintegration (at 16-160 $\mu \mathrm{g} / \mathrm{mL}$ in Figures 3 and 4 and Table S5) and loss of clonogenicity (at 8-16 $\mu \mathrm{g} / \mathrm{mL}$ in Table 4). In details, the high levels of ROS at the $5 \mathrm{~h}$-treated cells at $4 \mu \mathrm{g} / \mathrm{mL}$ activate apoptosis pathway capable of inducing ACD (Figure 2). We hypothesized that the adaptive response of $C$. neoformans showing elevated ROS production promotes stress resistance to $5 \mathrm{~h}$. Contrariwise, decrease in the ROS level by incubation with $5 \mathrm{~h}$ can induce the lethal process adequately monitored by cytometric analysis (Figures 3 and 4 and Table S5). Based on the latter findings, $5 \mathbf{h}$ can act such as anti-oxidant. Moreover, elevated ROS under $5 \mathrm{~h}$ correlated with fungicidal effect typical for AmB [44].

We used Rho123 as a membrane-potential-sensitive cationic fluorophore [45] to show that it was not able to leave the mitochondrion due to decreased membrane potential as a result of the $\mathbf{5 h}$-treated cell death (Figures 2-4, Figures 9 and 10 as well as Tables S4 and S5). We concluded that $5 \mathrm{~h}$ can be mitochondrial inhibitor of C. albicans ref and C. neoformans. Contrariwise, the Rho123 efflux simply increased pump activity in the 5 h-treated C. albicans isolate resistant to azoles. The compelling evidence for reduced filamentation and ACD (progenitors of mycoses) are targets for dibromobenzimidazole. Finally, our findings suggested a general strategy for antimycotics development that might be useful in limiting the emergence of fungal resistance. We selected $5 \mathrm{~h}$ as the most compound with significant response against the fungal virulence factors. We propose that $5 \mathrm{~h}$ acts synergistically to disrupt the $C$. albicans cell wall/membrane. These structures establish an excellent target for specific inhibition of pathogenic fungi.

\section{Materials and Methods}

\subsection{General Remarks of the N-Phenacyl Dibromobenzimidazole Derivatives Synthesis}

Commercially available reagents from Sigma Aldrich (Darmstadt, Germany), Fluka (Charlotte, NC, USA) and Avantor (Gliwice, Poland) were used as supplied. The measured melting points were not corrected. The column chromatography was performed using Silica gel 60 (Merck) of 40-63 $\mu \mathrm{m}$. Thin-layer chromatography was carried out on TLC aluminium plates with silica gel Kieselgel $60 \mathrm{~F}_{254}$ (Merck, Darmstadt, Germany) $(0.2 \mathrm{~mm}$ thickness film). The ${ }^{1} \mathrm{H}$ and ${ }^{13} \mathrm{C}$ NMR spectra were measured with a Varian 500 spectrometer operating at $500 \mathrm{MHz}$ for ${ }^{1} \mathrm{H}$ and $125 \mathrm{MHz}$ for ${ }^{13} \mathrm{C}$ nuclei. Chemical shifts $(\delta)$ are given in parts per million (ppm); signal multiplicity assignment: s, singlet; $d$, doublet; dd, doublet of doublets; m, multiplet; coupling constant (J) are given in hertz (Hz). High resolution 
mass spectrometry (HRMS) was carried out on Q Exactive Hybrid Quadrupole-Orbitrap Mass Spectrometer (Bremen, Germany), ESI (electrospray) with spray voltage $4.00 \mathrm{kV}$ at Institute of Biochemistry and Biophysics Polish Academy of Science (IBB PAS, Warsaw, Poland. The most intensive signals are reported.

\subsubsection{Synthesis of $\mathbf{4 a - d}$ and $5 \mathbf{a}-\mathbf{d}$}

To a stirred suspension of 5,6-dibromobenzimidazole 1 or 4,6-dibromobenzimidazole 2 ( $1 \mathrm{mmol}, 0.276 \mathrm{~g})$ in $\mathrm{MeCN}(20 \mathrm{~mL}) \mathrm{K}_{2} \mathrm{CO}_{3}(4 \mathrm{mmol}, 0.553 \mathrm{~g})$ followed by $3 \mathbf{a}-\mathbf{d}(1 \mathrm{mmol})$ was added. The reaction was carried out at room temperature $\left(20-22{ }^{\circ} \mathrm{C}\right)$ for $24 \mathrm{~h}$. After this time the solid products were filtered, washed out with MeCN $(25 \mathrm{~mL})$, evaporated. The residue was purified by column chromatography (silica gel $/ \mathrm{CHCl}_{3}$, eluent $\mathrm{CHCl}_{3}$ ). Analytical sample was crystallized (EtOH).

\subsubsection{Synthesis of $4 \mathbf{e}-\mathbf{i}$ and $5 \mathbf{e}-\mathbf{i}$}

To a stirred suspension of 5,6-dibromobenzimidazole 1 or 4,6-dibromobenzimidazole 2 (1 mmol, $0.276 \mathrm{~g})$ in $\mathrm{MeCN}(20 \mathrm{~mL}) \mathrm{K}_{2} \mathrm{CO}_{3}(8 \mathrm{mmol}, 1.106 \mathrm{~g})$ followed by $\mathbf{3 e}-\mathbf{j}(2 \mathrm{mmol})$ was added. The reaction was carried out at room temperature $\left(20-22{ }^{\circ} \mathrm{C}\right)$ for $3 \mathrm{~h}$ for $3 \mathbf{e}-\mathbf{i}$ and $96 \mathrm{~h}$ for $3 \mathbf{j}$. After this time the solid products were filtered, washed out with $\mathrm{MeCN}$ (25 mL), evaporated. The residue was purified twice by column chromatography (silica gel/ $\mathrm{CHCl}_{3}$, eluent $\mathrm{CHCl}_{3}$ followed by silica gel/toluene, eluent toluene/EtOAc gradient, 50:0 to 50:15). Analytical sample was crystallized (EtOH).

\subsection{Biological Studies \\ 4.2.1. Yeast Cultures}

Antifungal activity of new $N$-phenacyldibromobenzimidazole derivatives was carried out against two C. albicans strains: reference C. albicans SC5314 from American Type Culture Collection (ATCC) and clinical SPZ176 strain (resistant to antifungal drugs: fluconazole Flu and itraconazole Itr) and clinical C. neoformans SPZ173 strain (naturally resistant to echinocandins). Fungal strains were stored at $-80{ }^{\circ} \mathrm{C}$ in Microbank system (ProLab Diagnostics, Richmond Hill, ON, Canada) and cultured for $24 \mathrm{~h}$ at $30{ }^{\circ} \mathrm{C}$ with shaking at $100 \mathrm{rpm}$ prior to each examination in liquid medium: YEPD (Yeast Extract Peptone Dextrose) or YNB (Yeast Nitrogen Base 0.67\% w/v, glucose 2\% w/v, CSM-URA 0.077\% $w / v$, sterile water). After centrifugation at $3000 \mathrm{rpm}$ at $4{ }^{\circ} \mathrm{C}$ for $5 \mathrm{~min}$, cells were washed twice with sterile water and resuspended to prepare suspensions for experiments (ranging from $1.9 \times 10^{7}$ to $2.0 \times 10^{11} \mathrm{cfu} / \mathrm{mL}$; where $\mathrm{cfu} / \mathrm{mL}=($ number of colonies $) \times$ (inverse dilution of coefficient plated) $\times 10$.

\subsubsection{Broth Microdilution Assay: MIC and MFC Determination}

Stock solutions of $1600 \mu \mathrm{g} / \mathrm{mL}$ were prepared by dissolving the following compounds: $\mathbf{4 a}, \mathbf{4 j}, \mathbf{5 b}, \mathbf{5 d}, \mathbf{5 e}, \mathbf{5 f}, \mathbf{5 h}$, and $\mathbf{5 j}$ in $96 \%$ DMSO. Concentrations of 800,400 and $200 \mu \mathrm{g} / \mathrm{mL}$ were later prepared form stock solutions and stored at $-20^{\circ} \mathrm{C}$. Antifungal susceptibility testing was performed by broth microdilution assay according to the method M27-A3 by CLSI (Clinical and Laboratory Standards Institute) [27]. The microtiter plates were prepared containing compound test wells (CTW), sterility control wells (STW) and growth control wells (GCW) in triplicate in YEPD or YNB liquid medium. Compounds were added to proper wells (CTW and STW) to final concentration of 16,8 and $4 \mu \mathrm{g} / \mathrm{mL}$. Initial yeast suspensions (prepared as described above) were diluted 105-fold in sterile water and 20-fold in liquid medium before examination and then added to wells (CTW and GCW). To obtain the same concentration of DMSO in each well, DMSO was also added to growth control wells. Microtiter plates were incubated for $48 \mathrm{~h}$ at $30^{\circ} \mathrm{C}$. After $48 \mathrm{~h}$ visual assessments and absorbance measurements at $405 \mathrm{~nm}$ were performed using Synergy H4 Hybrid Reader (BioTek Instruments, Winooski, VT, USA). Antifungal activity was calculated as the percentage of cell growth inhibition using formula: \% of inhibition = $100 \times(1-($ ODCTW - ODSCW $) /($ ODGCW - ODSCW $)$, were OD means absorbance of 
each well. CTWs containing each concentration of tested compounds were mixed and diluted $10^{4}$-fold in sterile water. Then, $100 \mu \mathrm{L}$ of each suspension was spread on the plates containing solid YEPD or YNB medium and incubated at $30^{\circ} \mathrm{C}$ for $48 \mathrm{~h}$. After $48 \mathrm{~h}$, visual assessments were performed and Colony Forming Unit per $1 \mathrm{~mL}$ (cfu/mL) was calculated. Logarithmic cfu growth reduction factor $(\mathrm{R})$ was calculated by formula: $\mathrm{R}=\log (\mathrm{cfu} / \mathrm{mL}$ GCW) - $\log (\mathrm{cfu} / \mathrm{mL}$ CTW). Minimum Fungicidal Concentration (MFC) was determined as the concentration which resulted in $\geq 99.9 \% \mathrm{CFU} / \mathrm{mL}$ reduction $(\mathrm{R}>3)$.

\subsubsection{Determination of $\mathbf{5 e -} \mathbf{f}$ and $\mathbf{5 h}$ Cytotoxicity}

Cytotoxicity evaluation was performed using MTS reagent (3-(4,5-dimethylthiazol-2yl)-5-(3-carboxymethoxyphenyl)-2-(4-sulfophenyl)-2H-tetrazolium, MTS, Promega, USA) against mammal Vero cell line (ATCC CCL-81, LGC Standards, Lomianki, Poland). Vero cell line was cultured in vitro at $37^{\circ} \mathrm{C}$ and $5 \% \mathrm{CO}_{2}$ in EMEM medium (Eagle's Minimum Essential Medium, Sigma-Aldrich, St. Louis, MO, USA) supplemented with 10\% FBS (foetal bovine serum, Gibco, Waltham, MA, USA) and 1\% antibiotics. Cells were passaged several times and eventually transferred to microtiter plate (final density of 400,000 cells per $\mathrm{mL}$ ) and incubated for $24 \mathrm{~h}$ prior to examination [46]. Resulting cell monolayer was maintained in EMEM medium supplemented with 10\% FBS. Stock solutions of each comp. were prepared (conc. of $512 \mu \mathrm{g} / \mathrm{mL}$ ) and added in triplicate in 2-fold dilutions to the plate until final conc. of $0.125 \mu \mathrm{g} / \mathrm{mL}$. Positive control with cells and without tested comp. and negative control without cells were also prepared. After $24 \mathrm{~h}$ of incubation, $10 \mu \mathrm{L}$ of MTS reagent was added to each well and the plates were incubated for $3 \mathrm{~h}$ in darkness [46]. Finally, the absorbance at 490 and $660 \mathrm{~nm}$ was measured with Synergy H4 Hybrid Reader (BioTek Instruments, Winooski, VT, USA) and specific absorbance (SA) was calculated as follows: $\mathrm{SA}=\mathrm{A}_{490}-\mathrm{A}_{660}$. Viability of Vero cells was calculated using formula: $\%$ viability $=($ SA Test - SA Blank $) /($ SA Positive control - SA Blank $) \times 100$, and the cytotoxicity of the compounds: \% cytotoxicity $=($ SA Positive control - SA Test $) /($ SA Positive control SA Blank) $\times 100$ [41].

\subsubsection{Broth Microdilution Assay: Activity of $5 \mathrm{~h}$ Accompanied by Osmotic Protector}

The evaluation of antifungal activity of $5 \mathbf{h}$ against clinical C. albicans SPZ176 and C. neoformans SPZ173 strains was performed by the CLSI M27-A3 method described above with modifications. Compound test wells (CTW), sterility control wells (STW) and growth control wells (GCW) were prepared as previously mentioned in liquid medium consisting of YNB and 0.8 M sorbitol (Sigma-Aldrich, USA) as an osmotic protector [34]. Plates were incubated for $120 \mathrm{~h}$ at $30^{\circ} \mathrm{C}$. Absorbance was measured at $405 \mathrm{~nm}$ after 96 and $120 \mathrm{~h}$ of incubation using Synergy H4 Hybrid Reader (BioTek Instruments, USA). Antifungal activity was calculated as the percentage of cell growth inhibition using formula presented above.

\subsubsection{Examination of Chitinolytic Activity of $5 \mathbf{h}$}

Test was preformed using Chitinase Assay Kit (CS0980, Sigma-Aldrich, USA). Procedure was based on technical bulletin obtained from producer [30]. Four groups of samples were prepared on microtiter plate: (1) Blanc $-40 \mu \mathrm{L}$ of substrate A, B or C; (2) Standard$120 \mu \mathrm{L}$ of standard solution (included in Assay Kit); (3) Test-36 $\mu \mathrm{L}$ of substrate A, B or C with $5 \mathrm{~h}$ to final concentration of $16 \mu \mathrm{g} / \mathrm{mL}(4 \mu \mathrm{L}$ of $5 \mathrm{~h}$ at $160 \mathrm{mg} / \mathrm{mL})$; (4) Control-36 $\mu \mathrm{L}$ of substrate A, B or C with $4 \mu \mathrm{L}$ of $0.2 \mathrm{mg} / \mathrm{mL}$ chitinase. Plate was incubated for $30 \mathrm{~min}$ at $37^{\circ} \mathrm{C}$ and then the reaction was stopped with stop solution form the Assay Kit. Absorbance at $405 \mathrm{~nm}$ was measured using Synergy H4 Hybrid Reader (BioTek Instruments, USA) [27]. Chitinolytic activity was calculated using formula:

$$
\mathrm{ACT}=\frac{\left(A_{\mathrm{T}}-A_{\mathrm{B}}\right) \times 0.05 \times 0.07 \times D F}{A_{\mathrm{S}} \times \mathrm{t} \times V_{\mathrm{PR}}}
$$

where: ACT—chitinolytic activity [U/mL]; $A_{\mathrm{T}}$-absorbance of test sample at $405 \mathrm{~nm}[-]$; $A_{\mathrm{B}}$-absorbance of blank at $405 \mathrm{~nm}[-] ; 0.05-p$-nitrofenol concentration in standard so- 
lution $[\mu \mathrm{mol} / \mathrm{mL}] ; 0.07$-final volume of samples in each test well (after addition of stop solution) [mL]; DF-enzyme dilution factor (here equal to 1 -enzyme was not diluted); $A_{\mathrm{S}}$-absorbance of standard [-]; t-reaction duration time [min]; $V_{\mathrm{PR}}$-volume of $5 \mathbf{h}$ or chitinase [mL] (here $0.004 \mathrm{~mL}$ ).

\subsubsection{Determination of the Rhodamine 123 Efflux from the Cells Treated with $\mathbf{5 h}$}

C. albicans SC5314 ref. strain's, C. albicans SPZ176 clinical strains and C. neoformans SPZ173 clinical strain's culture were prepared as previously described. Test samples were prepared by adding of $100 \mu \mathrm{L}$ of $10^{5}$-fold diluted cells suspensions to $900 \mu \mathrm{L}$ YNB medium with $5 \mathrm{~h}$ at conc. of 160,16 or $4 \mu \mathrm{g} / \mathrm{mL}$. Control was obtained by adding $10^{5}$-fold diluted cells suspensions to $900 \mu \mathrm{L}$ YNB without $5 \mathrm{~h}$. All samples were incubated at $30^{\circ} \mathrm{C}$ with shaking at $120 \mathrm{rpm}$ for $18 \mathrm{~h}$. Suspensions were then centrifuged at $9500 \mathrm{rpm}$ for $2 \mathrm{~min}$ and cells were washed with PBS. Following, $100 \mu \mathrm{L}$ of the washed cells were added to $900 \mu \mathrm{L}$ of PBS with glucose $(5 \mathrm{mM})$ and rhodamine B $(7.18 \mathrm{mg} / \mathrm{mL})$ (Sigma-Aldrich, Darmstadt, Germany). After $30 \mathrm{~min}$ of incubation at $37^{\circ} \mathrm{C}$, suspensions were centrifuged at $9500 \mathrm{rpm}$ for $2 \mathrm{~min}$ and the cells were washed with PBS. Then, the cells were resuspended in PBS with glucose $(1 \mathrm{mM})$ and incubated at $37{ }^{\circ} \mathrm{C}$ with shaking at $120 \mathrm{rpm}$ for $18 \mathrm{~h}$. Then, the post growth medium was separated from the cells by centrifugation at $9500 \mathrm{rpm}$ for $2 \mathrm{~min}$ and $20 \mu \mathrm{L}$ of supernatant was added to microtiter plate. To prepare 10 -fold diluted samples, $180 \mu \mathrm{L}$ of sterile water was added to each well. Fluorescence was measured with excitation at $521 \mathrm{~nm}$ and emission at $627 \mathrm{~nm}$ using Synergy H4 Hybrid Reader (BioTek Instruments, Winooski, VT USA). Concentration of Rho123 was calculated using formula: $\mathrm{C}=(\mathrm{E}-\mathrm{Blank}$ - 1151.2) × 10/556.91; where: E-emission; Blank—emission of PBS/glucose medium; 1151.2 and 556,91—coefficients of rhodamine standard curve; 10 - dilution coefficient. Decrease of the Rho123 content was determined using the formula: $\Delta \mathrm{C} \%=[\mathrm{C}(\mathrm{Test})-$ $\mathrm{C}($ Control $)] / \mathrm{C}($ Control $) \times 100$; where: $\mathrm{C}($ Test $)$ - concentration of rhodamine in tested samples; C(Control)—concentration of rhodamine in control samples [45].

4.2.7. Determination of Reactive Oxygen Species (ROS) Concentration after Incubation with $5 \mathrm{~h}$

Examination was preformed using DCFDA/H2DCFDA kit (Thermo Fisher Scientific, Waltham, MA, USA) [45]. C. albicans SC5314, C. albicans SPZ 176 clinical isolate and C. neoformans SPZ 173 clinical isolate were prepared as previously described. Test samples were prepared as described in Rho123 assay (see Section 4.2.6). Positive control treated with hydrogen peroxide at conc. of $3 \%$ and untreated negative control were used. Test and control tubes were incubated for at $30{ }^{\circ} \mathrm{C}$ with shaking at $120 \mathrm{rpm}$ for $18 \mathrm{~h}$. Suspensions were then centrifuged at $5000 \mathrm{rpm}$ for $5 \mathrm{~min}$ and cells were washed with PBS. Then, $999.5 \mu \mathrm{L}$ of the cell suspension was transferred to new test tube and $0.5 \mu \mathrm{L}$ of fluorescein solution $(10 \mathrm{mM})$ in DMSO $(96 \%)$ was added. All samples were incubated for at $30^{\circ} \mathrm{C}$ with shaking at $120 \mathrm{rpm}$ for $40 \mathrm{~min}$. Test samples (without positive control) were centrifuged at $5000 \mathrm{rpm}$ for $5 \mathrm{~min}$ and cells were resuspended in YNB medium. Then, all samples were incubated at $30{ }^{\circ} \mathrm{C}$ with shaking at $120 \mathrm{rpm}$ for $18 \mathrm{~h}$. The positive control was transferred on a microtiter plate as well as 10 -fold dilution of test samples. Fluorescence was measured with extinction at $485 \mathrm{~nm}$ and emission at $530 \mathrm{~nm}$ using Synergy H4 Hybrid Reader (BioTek Instruments, Winooski, VT, USA). Change in ROS concentration was calculated using formula: $\Delta \mathrm{C}=[\mathrm{E}($ Test $)-\mathrm{E}(\mathrm{Control})] \times 100 \% / \mathrm{E}($ Control $)$; where $\Delta \mathrm{C}$-change in ROS concentration; $\mathrm{E}($ Test $)$-fluorescence of test samples; $\mathrm{E}(\mathrm{Control})$-fluorescence of negative control [45].

\subsubsection{Cytometric Analysis of Cell Death Type}

To determine the type of cell death induced by the action of $5 \mathbf{h}$, flow cytometry analysis was performed using the protoplasts and C. albicans SPZ176 and C. neoformans SPZ173 cells. Protoplasts were obtained according to the method previously described [41]. Cells and protoplasts were then incubated with 160,16 or $4 \mu \mathrm{g} / \mathrm{mL}$ of $5 \mathrm{~h}$ at $30^{\circ} \mathrm{C}$ with shaking at $120 \mathrm{rpm}$ for $24 \mathrm{~h}$. Compound-free growth controls were also prepared. After harvesting 
by centrifugation at $3000 \mathrm{rpm}$ at $4{ }^{\circ} \mathrm{C}$ for $5 \mathrm{~min}$; cells were washed and resuspended with sterile water. Determination of the cell death type was conducted by staining using annexin $\mathrm{V}$ and propidium iodide (FITC Annexin V/Dead Cell Apoptosis Kit with FITC annexin $\mathrm{V}$ and PI, for Flow Cytometry, (Invitrogen, Waltham, MA, USA) [42]. Suspensions were diluted by 10-fold with the proper buffer from the kit and then incubated for 10-15 min with $1 \mu \mathrm{L}$ of annexin. After centrifugation at $3000 \mathrm{rpm}$ at $4{ }^{\circ} \mathrm{C}$ for $5 \mathrm{~min}$ cells and protoplasts were resuspended in the buffer and incubated in ice for $5-15$ min with $1 \mu \mathrm{L}$ of propidium iodide (PI). Fluorescence was analysed by flow cytometry using BD FACSLyrics 2L6C with FACSuite Software 1.4 RUO (BD Biosciences, Mississauga, ON, Canada).

4.2.9. Confocal Laser Scanning Microscopy (CLSM) Analyses of the C. albicans and C. neoformans Biofilms Treated with $5 \mathbf{h}$

C. albicans SPZ 176 and clinical C. neoformans SPZ 173 cultures were prepared, as previously described [41]. Suspensions were centrifuged at $5000 \mathrm{rpm}$ at $4{ }^{\circ} \mathrm{C}$ for $5 \mathrm{~min}$ and resuspended in $2 \mathrm{~mL}$ of the YNB medium. Then, $500 \mu \mathrm{L}$ of suspensions were placed on coverslips on the bottom of a 24 well plate (two wells were prepared for each strain). Plate was then incubated at $37^{\circ} \mathrm{C}$ for $24 \mathrm{~h}$ without shaking. Then, the plate was washed twice with PBS. To the tested well, $500 \mu \mathrm{L}$ of $5 \mathrm{~h}$ solution in PBS (final conc. of $16 \mu \mathrm{g} / \mathrm{mL}$ ) was added (test sample), to the control one $500 \mu \mathrm{L}$ PBS was added. Plate was incubated at $37^{\circ} \mathrm{C}$ for $18 \mathrm{~h}$. Biofilms were then washed twice with PBS and then $495 \mu \mathrm{L}$ of PBS and $5 \mu \mathrm{L}$ of staining solution was added. The following staining solutions were used: CR (Congored, Sigma-Aldrich) at stock conc. of $200 \mu \mathrm{g} / \mathrm{mL}$; CFW (Calcofluor White, Sigma-Aldrich) at stock conc. of $250 \mu \mathrm{g} / \mathrm{mL}$; AO (Acridine Orange, Roche Diagnostics $\mathrm{GmbH}$, Mannheim, Germany) at stock conc. of $100 \mu \mathrm{g} / \mathrm{mL}$; EB (Ethidium Bromide, Roche Diagnostics $\mathrm{GmbH}$ ) at stock conc. of $100 \mu \mathrm{g} / \mathrm{mL}$ [41]. Final staining solutions were diluted by 100 -fold. The plate was incubated at $37^{\circ} \mathrm{C}$ for $18 \mathrm{~h}$. Microscope observations were carried out using confocal laser scanning microscopy (CLSM) with Olympus FLUOREVIEW FV1000 (Olympus, Osaka, Japan).

Supplementary Materials: The following are available online. Analytical data of compounds $4 \mathbf{a}$, $4 \mathbf{j}, \mathbf{5 b}, \mathbf{5 d}, \mathbf{5 e}, \mathbf{5 f}, \mathbf{5 h}, 5 \mathbf{j} ;{ }^{1} \mathrm{H}$ and ${ }^{13} \mathrm{C}$ NMR of compounds $4 \mathbf{a}, 4 \mathbf{j}, \mathbf{5 b}, \mathbf{5 d}, \mathbf{5 e}, \mathbf{5 f}, \mathbf{5 h}, 5 \mathbf{j}$; HRMS of compounds $4 \mathbf{a}, \mathbf{4 j}, \mathbf{5 b}, \mathbf{5 d}, \mathbf{5 e}, \mathbf{5 f}, \mathbf{5 h}, \mathbf{5 j}$; Figures S1-S12. Cell growth inhibition under $\mathbf{4 b}, \mathbf{4 c}, \mathbf{4 d}$, $4 \mathrm{e}, \mathbf{4 f}, \mathbf{4 g}, \mathbf{4 h}, \mathbf{4 i}, \mathbf{5 a}, \mathbf{5 c}, \mathbf{5 g}$, 5i; Figure S13. Cytotoxicity of phenacyl dibromide derivatives; Table S1. Characteristics of 4,6-dibromidebenzimidazol N-phenacyl derivates; Table S2. Viability of Vero cells treated with phenacyl dibromide derivatives; Table S3. Cytotoxicity of phenacyl dibromide derivatives; Table S4. Change in ROS content $[\triangle C \pm R S D$ ] in post growth medium of $C$. albicans SC5314, C. albicans SPZ176 or C. neoformans SPZ173 treated with 5h compared to untreated control; Table S5. Fractions of live, necrotic, early, and late apoptosis C. albicans SPZ176 and C. neoformans SPZ173 cells and protoplasts (P), treated with different concentration of $5 \mathbf{h}$.

Author Contributions: Conceptualization, M.S. and A.K.; methodology, M.S. and A.K.; software, J.B.; validation, M.S., A.K., and L.K.; formal analysis, M.S.; investigation, A.G. and J.K.; resources, A.G.; data curation, A.G.; writing — original draft preparation, A.G., M.S. and J.K.; writing—review and editing, M.S.; visualization, M.R. and A.G; supervision, M.S. and Ł.K.; project administration, M.S.; funding acquisition, M.S. All authors have read and agreed to the published version of the manuscript.

Funding: M.S. was financed by the Centre for Advanced Materials and Technologies CEZAMAT, Warsaw University of Technology, Poland. Ł.K. was supported by the grant (BW-3/2021 and 1BWBW / 2021) funded by the National Institute of Public Health (NIH)-National Research Institute (NIPH NIH-NRI), Poland. M.R., A.G., J.K. and J.B. were supported by the Faculty of Chemistry, Warsaw University of Technology, Poland. A.K. was supported by the Faculty of Chemistry, Warsaw University of Technology, Poland.

Institutional Review Board Statement: Not applicable.

Informed Consent Statement: Not applicable.

Data Availability Statement: Not available. 
Conflicts of Interest: The authors declare no conflict of interest.

Sample Availability: Not available.

\section{References}

1. Pierce, C.G.; Lopez-Ribot, J.L. Candidiasis drug discovery and development: New approaches targeting virulence for discovering and identifying new drugs. Expert Opin. Drug Discov. 2013, 8, 1117-1126. [CrossRef]

2. Lu, Y.; Su, C.; Liu, H. Candida albicans hyphal initiation and elongation. Trends Microbiol. 2014, 22, 707-714. [CrossRef]

3. Leite, M.C.; Bezerra, A.P.; de Sousa, J.P.; Guerra, F.Q.; Lima Ede, O. Evaluation of Antifungal Activity and Mechanism of Action of Citral against Candida albicans. Evid. Based Complement. Altern. Med. 2014, 2014, 378280. [CrossRef] [PubMed]

4. Shafiei, M.; Peyton, L.; Hashemzadeh, M.; Foroumadi, A. History of the development of antifungal azoles: A review on structures, SAR, and mechanism of action. Bioorg. Chem. 2020, 104, 104240. [CrossRef] [PubMed]

5. Emami, S.; Foroumadi, A.; Falahati, M.; Lotfali, E.; Rajabalian, S.; Ebrahimi, S.A.; Farahyar, S.; Shafiee, A. 2-Hydroxyphenacyl azoles and related azolium derivatives as antifungal agents. Bioorg. Med. Chem. Lett. 2008, 18, 141-146. [CrossRef] [PubMed]

6. Olender, D.; Żwawiak, J.; Lukianchuk, V.; Lesyk, R.; Kropacz, A.; Fojutowski, A.; Zaprutko, L. Synthesis of some N-substituted nitroimidazole derivatives as potential antioxidant and antifungal agents. Eur. J. Med. Chem. 2009, 44, 645-652. [CrossRef]

7. Nelson, R.; Kesternich, V.; Pérez-Fehrmann, M.; Salazar, F.; Marcourt, L.; Christen, P.; Godoy, P. Synthesis and Antifungal activity of phenacyl azoles. J. Chem. Res. 2014, 38, 549-552. [CrossRef]

8. Olender, D.; Zaprutko, L.; Mertas, A.; Szliszka, E.; Wyrozumski, D.; Król, W. Anti-Candida Activity of 4-Morpholino-5-Nitro- and 4,5-Dinitro-Imidazole Derivatives. Pharm. Chem. J. 2018, 51, 1063-1067. [CrossRef]

9. Elejalde, N.R.; Macías, M.; Castillo, J.C.; Sortino, M.; Svetaz, L.; Zacchino, S.; Portilla, J. Synthesis and in vitro Antifungal Evaluation of Novel N-Substituted 4-Aryl-2-methylimidazoles. Chem. Sel. 2018, 3, 5220-5227. [CrossRef]

10. Sari, S.; Kart, D.; Öztürk, N.; Kaynak, F.B.; Gencel, M.; Taşkor, G.; Karakurt, A.; Saraç, S.; Eşsiz, Ş.; Dalkara, S. Discovery of new azoles with potent activity against Candida spp. and Candida albicans biofilms through virtual screening. Eur. J. Med. Chem. 2019, 179, 634-648. [CrossRef]

11. Shaker, Y.M.; Omar, M.A.; Mahmoud, K.; Elhallouty, S.M.; El-Senousy, W.M.; Ali, M.M.; Mahmoud, A.E.; Abdel-Halim, A.H.; Soliman, S.M.; El Diwani, H.I. Synthesis, in vitro and in vivo antitumor and antiviral activity of novel 1-substituted ben-zimidazole derivatives. J. Enzym. Inhib. Med. Chem. 2015, 30, 826-845. [CrossRef]

12. Kamil, A.; Akhter, S.; Ahmed, M.; Rizwani, G.H.; Hassan, S.; Naeem, S.; Jahan, S.; Khursheed, R.; Zahid, H. Antimalarial and insecticidal activities of newly synthesized derivatives of Benzimidazole. Pak. J. Pharm. Sci. 2015, 28, $2179-2184$.

13. Panchal, S.N.; Vekariya, R.H.; Patel, K.D.; Prajapati, S.M.; Rajani, D.P.; Rajani, S.D.; Patel, H.D. An efficient synthesis of novel carbohydrate and thiosemicarbazone hybrid benzimidazole derivatives and their antimicrobial evaluation. Indian J. Chem. 2016, $55 B, 604-612$.

14. Vargas-Oviedo, D.; Butassi, E.; Zacchino, S.; Portilla, J. Eco friendly synthesis and antifungal evaluation of $N$ substituted benzimidazoles. Mon. Chem.-Chem. Mon. 2020, 151, 575-588. [CrossRef]

15. Zhang, H.; Lin, J.; Rasheed, S.; Zhou, C. Design, synthesis, and biological evaluation of novel benzimidazole derivatives and their interaction with calf thymus DNA and synergistic effects with clinical drugs. Bioorg. Med. Chem. Lett. 2012, 22, 5363-5366. [CrossRef]

16. Kumar, V.; Kaur, K.; Karelia, D.N.; Beniwal, V.; Gupta, G.K.; Sharma, A.K.; Gupta, A.K. Synthesis and biological evaluation of some 2-(3,5-dimethyl-1H-pyrazol-1-yl)-1-arylethanones: Antibacterial, DNA photocleavage, and anticancer activities. Eur. J. Med. Chem. 2014, 81, 267-276. [CrossRef]

17. Jacob, K.S.; Ganguly, S. Synthesis, antimicrobial screening and cytotoxic studies of some novel pyrazole analogs. J. Appl. Pharm. Sci. 2016, 6, 135-141. [CrossRef]

18. Karki, R.G.; Gokhale, V.M.; Kharkar, P.S.; Kulkarni, V.M. Azole compounds designed by molecular modelling show antifungal activity as predicted. Indian J. Chem. 2003, 42B, 372-381. [CrossRef]

19. Gaikwad, N.D.; Patil, S.V.; Bobade, V.D. Hybrids of ravuconazole: Synthesis and biological evaluation. Eur. J. Med. Chem. 2012, 54, 295-302. [CrossRef]

20. Gaikwad, N.D.; Patil, S.V.; Bobade, V.D. Synthesis and biological evaluation of some novel thiazole substituted benzotriazole derivatives. Bioorg. Med. Chem. Lett. 2012, 22, 3449-3454. [CrossRef]

21. Meggio, F.; Shugar, D.; Pinna, L.A. Ribofuranosyl-benzimidazole derivatives as inhibitors of casein kinase-2 and casein kinase-1. Eur. J. Biochem. 1990, 187, 89-94. [CrossRef]

22. Genieser, H.G.; Winkler, E.; Butt, E.; Zorn, M.; Schulz, S.; Iwitzki, F.; Störmann, R.; Jastorff, B.; Døskeland, S.O.; Øgreid, D.; et al. Derivatives of $1-\beta$-d-ribofuranosylbenzimidazole $3^{\prime}, 5^{\prime}$-phosphate that mimic the actions of adenosine $3^{\prime}, 5^{\prime}$-phosphate (cAMP) and guanosine $3^{\prime}, 5^{\prime}$-phosphate (cGMP). Carbohydr. Res. 1992, 234, 217-235. [CrossRef]

23. Zou, R.; Drach, J.C.; Townsend, L.B. Interaction of the putative human cytomegalovirus portal protein pUL104 with the large terminase subunit pUL56 and its inhibition by benzimidazole-D-ribonucleosides. J. Med. Chem. 1997, 40, 811-818. [CrossRef]

24. Mancebo, H.S.Y.; Lee, G.; Flygare, J.; Tomassini, J.; Luu, P.; Zhu, Y.; Peng, J.; Blau, C.; Hazuda, D.; Price, D.; et al. P-TEFb kinase is required for HIV Tat transcriptional activation in vivo and in vitro. Gene. Dev. 1997, 11, 2633-2644. [CrossRef]

25. Kowalkowska, A.; Chojnacki, K.; Wińska, P.; Mierzejewska, J.; Lewiński, R. Optimization of N-phenacyldibromobenzimidazole synthesis. in preparation. 
26. Stover, K.R.; Cleary, J.D. The Eagle-Like Effect of the Echinocandins: Is It Relevant for Clinical Decisions? Curr. Fungal Infect. Rep. 2015, 9, 88-93. [CrossRef]

27. Rex, J.H.; Alexander, B.D.; Andes, D.; Arthington-Skaggs, B.; Brown, S.D.; Chaturvedi, V.; Ghannoum, M.A.; Espinel-Ingroff, A.; Knapp, C.C.; Ostrosky-Zeichner, L.; et al. Reference Method for Broth Dilution Antifungal Susceptibility Testing of Yeast, 3rd ed.; Approved Standard M27-A3; Clinical and Laboratory Standards Institute: Wayne, PA, USA, 2008.

28. Carmona-Gutierrez, D.; Bauer, M.A.; Zimmermann, A.; Aguilera, A.; Austriaco, N.; Ayscough, K.; Balzan, R.; Bar-Nun, S.; Barrientos, A.; Belenky, P.; et al. Guidelines and recommendations on yeast cell death nomenclature. Microb. Cell 2018, 5, 4-31. [CrossRef]

29. Borowiecki, P.; Wińska, P.; Bretner, M.; Gizińska, M.; Koronkiewicz, M.; Staniszewska, M. Synthesis of Novel Proxyphylline Derivatives with Dual Anti-Candida albicans and Anticancer Activity. Eur. J. Med. Chem. 2018, 150, 307-333. [CrossRef]

30. Technical Bulletin: Chitinase Assay Kit (CS0980); Sigma-Aldrich: St. Louis, MO, USA, 2017; Available online: https://www. sigmaaldrich.com/deepweb/assets/sigmaaldrich/product/documents/105/220/cs0980bul.pdf (accessed on 20 June 2021).

31. Cantón, E.; Pemán, J.; Viudes, A.; Quindós, G.; Gobernado, M.; Espinel-Ingroff, A. Minimum fungicidal concentrations of amphotericin B for bloodstream Candida species. Diagn. Microbiol. Infect. Dis. 2003, 45, 203-206. [CrossRef]

32. Staniszewska, M.; Bondaryk, M.; Kazek, M.; Gliniewicz, A.; Braunsdorf, C.; Schaller, M.; Mora-Montes, H.M.; Ochal, Z. Effect of serine protease KEX2 on Candida albicans virulence under halogenated methyl sulfones. Future Microbiol. 2017, 12, 285-306. [CrossRef] [PubMed]

33. França, F.; Tagliati, C.; Ferreira, A.; Chaves, M.M. Amphotericin B nephrotoxicity in vitro: Differential profile of PKC signaling in VERO and MDCK cell lines. Curr. Top. Toxicol. 2014, 9, 15-19.

34. Pereira, J.V.; Freires, I.A.; Castilho, A.R.; da Cunha, M.G.; Alves Had, S.; Rosalen, P.L. Antifungal potential of Sideroxylon obtusifolium and Syzygium cumini and their mode of action against Candida albicans. Pharm. Biol. 2016, 54, 2312-2319. [CrossRef]

35. Górka-Nieć, W.; Perlińska-Lenart, U.; Zembek, P.; Palamarczyk, G.; Kruszewska, J.S. Influence of sorbitol on protein production and glycosylation and cell wall formation in Trichoderma reesei. Fungal Biol. 2010, 114, 855-862. [CrossRef]

36. Makarasen, A.; Reukngam, N.; Khlaychan, P.; Chuysinuan, P.; Isobe, M.; Techasakul, S. Mode of action and synergistic effect of valinomycin and cereulide with amphotericin B against Candida albicans and Cryptococcus albidus. J. Mycol. Méd. 2018, 28 , 112-121. [CrossRef]

37. Brand, A. Hyphal growth in human fungal pathogens and its role in virulence. Int. J. Microbiol. 2012, 2012, 517529. [CrossRef]

38. Tabata, E.; Wakita, S.; Kashimura, A.; Sugahara, Y.; Matoska, V.; Bauer, P.O.; Oyama, F. Residues of acidic chitinase cause chitinolytic activity degrading chitosan in porcine pepsin preparations. Sci. Rep. 2019, 9, 15609. [CrossRef]

39. Nielsen, M.N.; Sørensen, J. Chitinolytic activity of Pseudomonas fluorescens isolates from barley and sugar beet rhizosphere. FEMS Microbiol. Ecol. 1999, 30, 217-227. [CrossRef]

40. Shamly, V.; Kali, A.; Srirangaraj, S.; Umadevi, S. Comparison of Microscopic Morphology of Fungi Using Lactophenol Cotton Blue (LPCB), Iodine Glycerol and Congo Red Formaldehyde Staining. J. Clin. Diagn. Res. JCDR 2014, 8, DL01-DL02. [CrossRef] [PubMed]

41. Staniszewska, M.; Sobiepanek, A.; Gizińska, M.; Peña-Cabrera, E.; Arroyo-Córdoba, I.J.; Kazek, M.; Kuryk, Ł.; Wieczorek, M.; Koronkiewicz, M.; Kobiela, T.; et al. Sulfone derivatives enter the cytoplasm of Candida albicans sessile cells. Eur. J. Med. Chem. 2020, 191, 1121139. [CrossRef]

42. Eisenberg, T.; Carmona-Gutierrez, D.; Büttner, S.; Tavernarakis, N.; Madeo, F. Necrosis in yeast. Apoptosis 2010, 15, 257-268. [CrossRef]

43. Bahmed, K.; Bonaly, R.; Coulon, J. Relation between cell wall chitin content and susceptibility to amphotericin B in Kluyveromyces, Candida and Schizosaccharomyces species. Res. Microbiol. 2003, 154, 215-222. [CrossRef]

44. Mesa-Arango, A.C.; Trevijano-Contador, N.; Román, E.; Sánchez-Fresneda, R.; Casas, C.; Herrero, E.; Argüelles, J.C.; Pla, J.; Cuenca-Estrella, M.; Zaragoza, O. The production of reactive oxygen species is a universal action mechanism of Amphotericin B against pathogenic yeasts and contributes to the fungicidal effect of this drug. Antimicrob. Agents Chemother. 2014, 58, 6627-6638. [CrossRef] [PubMed]

45. Saibabu, V.; Fatima, Z.; Khan, L.A.; Hameed, S. Vanillin Confers Antifungal Drug Synergism in Candida albicans by Impeding CaCdr2p Driven Efflux. J. Mycol. Med. 2020, 30, 100921. [CrossRef] [PubMed]

46. Product Information Sheet: Reactive Oxygen Species (ROS) Detection Reagents; Thermo Fisher Scientific: Waltham, MA, USA, 2005; Available online: https: / /www.thermofisher.com/order/catalog/product/C369?SID=srch-srp-C369?query=DCFDA\#/C369 ?SID=srch-srp-C369\%3Fqueryassets.thermofisher.com (accessed on 20 June 2021). 